\title{
Seasonal variation of nitrogen oxides in the central North Atlantic lower free troposphere
}

\author{
M. Val Martin, ${ }^{1,2}$ R. E. Honrath, ${ }^{1}$ R. C. Owen, ${ }^{1}$ and Q. B. $\mathrm{Li}^{3}$ \\ Received 7 December 2007; revised 14 May 2008; accepted 20 June 2008; published 6 September 2008.
}

[1] Measurements of $\mathrm{NO}, \mathrm{NO}_{2}$, and $\mathrm{NO}_{y}$ (total reactive nitrogen oxides) made at the Pico Mountain station, $38.47^{\circ} \mathrm{N}, 28.40^{\circ} \mathrm{W}, 2.2 \mathrm{~km}$ above sea level, from July 2002 to August 2005 are used to characterize the seasonal and diurnal variations of nitrogen oxides in the background lower free troposphere (FT) over the central North Atlantic Ocean. These observations reveal a well-defined seasonal cycle of nitrogen oxides $\left(\mathrm{NO}_{x}=\mathrm{NO}+\right.$ $\mathrm{NO}_{2}$ and $\mathrm{NO}_{y}$ ), with higher mixing ratios during the summertime. Observed $\mathrm{NO}_{x}$ and $\mathrm{NO}_{y}$ levels are consistent with long-range transport of emissions, with significant removal en route to the measurement site. Larger summertime nitrogen oxides levels are attributed to boreal wildfire emissions and more efficient export and transport of $\mathrm{NO}_{y}$ from eastern North America during that season. In addition, measurements of $\mathrm{NO}_{x}$ and $\mathrm{NO}_{y}$ obtained during in-cloud and cloud-free conditions are used to estimate $\mathrm{PAN}$ and $\mathrm{HNO}_{3}$ mixing ratios and examine the partitioning of the reactive nitrogen species. These estimates indicate that reactive nitrogen over the central North Atlantic lower FT largely exists in the form of $\mathrm{PAN}_{\text {and }} \mathrm{HNO}_{3}\left(\sim 80-90 \%\right.$ of $\left.\mathrm{NO}_{y}\right)$ year-round. The composition of $\mathrm{NO}_{y}$ shifts from dominance of PAN in winter-spring to dominance of $\mathrm{HNO}_{3}$ in summer-fall, as a result of changes in temperature and photochemistry over the region. A further comparison of the nitrogen oxides measurements with results from the global chemical transport model GEOS-Chem finds that simulated nitrogen oxides are significantly larger than the observations.

Citation: Val Martin, M., R. E. Honrath, R. C. Owen, and Q. B. Li (2008), Seasonal variation of nitrogen oxides in the central North Atlantic lower free troposphere, J. Geophys. Res., 113, D17307, doi:10.1029/2007JD009688.

\section{Introduction}

[2] Reactive nitrogen species are critical to the chemistry of the atmosphere. Photochemical production of $\mathrm{O}_{3}$ depends on the levels of $\mathrm{NO}_{x}\left(\mathrm{NO}+\mathrm{NO}_{2}\right)$, which in turn, influences the concentration of tropospheric $\mathrm{OH}$. Species that affect $\mathrm{OH}$ are important, as reaction with $\mathrm{OH}$ provides the dominant path for removal of a variety of atmospheric pollutants [Crutzen, 1979; Logan, 1983]. In addition, nitric acid, the primary end product of $\mathrm{NO}_{x}$ oxidation, is one of the major components of acid deposition [Crutzen, 1979].

[3] Understanding the impact of $\mathrm{NO}_{x}$ on tropospheric $\mathrm{O}_{3}$ on a global scale is important for several reasons. Tropospheric ozone is considered the third most important anthropogenic greenhouse gas [Intergovernmental Panel on Climate Change, 2007]. In addition, slightly elevated levels of $\mathrm{O}_{3}$, at concentrations not far above current ambient levels in many regions, pose a serious concern

\footnotetext{
${ }^{1}$ Department of Civil and Environmental Engineering, Michigan Technological University, Houghton, Michigan, USA.

${ }^{2}$ Now at School of Engineering and Applied Science, Harvard University, Cambridge, Massachusetts, USA.

${ }^{3}$ Jet Propulsion Laboratory, California Institute of Technology, Pasadena, California, USA.
}

Copyright 2008 by the American Geophysical Union. 0148-0227/08/2007JD009688\$09.00 because of their effects on the human respiratory system and ecosystems [Environmental Protection Agency (EPA), 2006]. In particular, there is an increasing concern regarding intercontinental transport of $\mathrm{O}_{3}$ pollution since it appears to be changing the composition of the background troposphere [Simmonds et al., 2004; Jaffe et al., 2003] and making it more difficult for countries downwind to achieve their air quality standards [Li et al., 2002; Derwent et al., 2004].

[4] In the Northern Hemisphere, emissions of nitrogen oxides are dominated by anthropogenic sources in urban and industrial regions [e.g., Logan, 1983; Richter et al., 2005]. In addition, as a result of increased area burned and fire frequency over the boreal region [Kasischke and Turetsky, 2006], emissions from boreal wildfires have resulted in a significant source of $\mathrm{NO}_{x}$ to the atmosphere during the summer season [Goode et al., 2000; Andreae and Merlet, 2001]. The impact of $\mathrm{NO}_{x}$ emissions from these sources on global $\mathrm{O}_{3}$ is limited as oxidation of $\mathrm{NO}_{x}$ to $\mathrm{HNO}_{3}$, peroxyacetyl nitrate (PAN) and other minor compounds occurs in less than 1 day in the continental boundary layer (BL). However, the rates of $\mathrm{O}_{3}$ production show a complex nonlinear dependence on $\mathrm{NO}_{x}$ [Liu et al., 1987]. This means that the number of $\mathrm{O}_{3}$ molecules produced per molecule of $\mathrm{NO}_{x}$ consumed, known as the $\mathrm{O}_{3}$ production efficiency, is greater for lower $\mathrm{NO}_{x}$ levels. As a result, the export of only a small fraction of emitted $\mathrm{NO}_{x}$ may lead to 
significant $\mathrm{O}_{3}$ production in the remote troposphere [Jacob et al., 1993]. The export of $\mathrm{NO}_{x}$ away from source regions is facilitated by the export of PAN, a thermally unstable, nearly insoluble species, out of the continental BL, followed by the transport of PAN on a global scale at cold temperatures, and decomposition to $\mathrm{NO}_{x}$ as the air masses become warmer [Moxim et al., 1996]. It has been suggested that, similar to PAN, the export of $\mathrm{HNO}_{3}$ followed by photolysis to $\mathrm{NO}_{x}$ can be an important source of $\mathrm{NO}_{x}$ even in the lower troposphere [Neuman et al., 2006]. Thus, quantifying the magnitude of nitrogen oxides and their chemical evolution in the remote troposphere is fundamental to understanding the impact of anthropogenic emissions on the global $\mathrm{O}_{3}$ budget.

[5] Field measurement campaigns have been conducted in the last two decades to characterize the spatial and temporal distribution of tropospheric $\mathrm{NO}_{x}$ and to determine the resulting effect of $\mathrm{NO}_{x}$ emissions on the $\mathrm{O}_{3}$ budget. However, data composites of results from many of these campaigns show that the spatial and temporal coverage of remote tropospheric $\mathrm{NO}_{x}$ measurements is still quite sparse and reflects a strong seasonal and regional bias [e.g., Emmons et al., 1997, 2000; Bradshaw et al., 2000; DiNunno et al., 2003].

[6] In addition to measurement campaigns, global chemical transport models (CTM) have been developed to derive the global impact of anthropogenic and boreal wildfire emissions on the $\mathrm{O}_{3}$ budget. However, it is difficult to assess the uncertainty of the resulting estimates, in particular those related to $\mathrm{NO}_{x}$ sources and photochemical processes. The evaluation of CTMs with nitrogen oxides observations in the free troposphere (FT) has been limited by a lack of data in remote regions [e.g., Thakur et al., 1999; Lawrence and Crutzen, 1999].

[7] Recently, satellite-derived data have been used to derive global and regional $\mathrm{NO}_{x}$ budgets [e.g., Leue et al., 2001; Martin et al., 2004; Jaeglé et al., 2005; Richter et al., 2005] and detect intercontinental transport of nitrogen oxides plumes from boreal wildfires [Spichtinger et al., 2001] and anthropogenic sources [Wenig et al., 2003; Stohl et al., 2003]. More recently, satellite data have been used to evaluate CTMs [e.g., Liu et al., 2006; Chandra et al., 2004]. However, limited measurements of nitrogen oxides in the remote lower FT make the evaluation of satellite-derived data difficult [Leue et al., 2001; Martin et al., 2004].

[8] The data presented in this paper constitute a multiyear record of $\mathrm{NO}, \mathrm{NO}_{x}$, and $\mathrm{NO}_{y}$ in the central North Atlantic lower FT determined at the Pico Mountain station. These data are analyzed to characterize the seasonal and diurnal variation of nitrogen oxides in the background lower FT over the central North Atlantic region. In addition, measurements of $\mathrm{NO}_{x}$ and $\mathrm{NO}_{y}$ made during in-cloud and cloud-free conditions are used to estimate PAN and $\mathrm{HNO}_{3}$ levels and examine the partitioning of the reactive nitrogen species over this region. Observations are also compared with simulations from the CTM model GEOS-Chem to assess our current understanding of the fate and transport of nitrogen oxides in the remote North Atlantic troposphere. Additional analyses are presented by Val Martin et al. [2008], in which we use these observations of nitrogen oxides in combination with simultaneous measurements of $\mathrm{CO}$ and $\mathrm{O}_{3}$ to assess the degree to which transport of anthropogenic and boreal wildfire emissions affect nitrogen oxides levels and the resulting implications for the hemispheric $\mathrm{NO}_{x}$ and $\mathrm{O}_{3}$ budgets.

\section{Methodology}

[9] Measurements of $\mathrm{NO}, \mathrm{NO}_{2}, \mathrm{NO}_{y}$ were made at the Pico Mountain station during extensive periods of time from 20 July 2002 to 25 August 2005. We present here measurements of nitrogen oxides analyzed in combination with measurements of $\mathrm{CO}$ also made at the Pico Mountain station. Because the Pico Mountain station and measurement details have already been described elsewhere [Honrath et al., 2004; Kleissl et al., 2007; Owen et al., 2006; Val Martin et al., 2006], only a brief summary of the most relevant experimental aspects is presented here.

\subsection{Measurement Site}

[10] The Pico Mountain station is located on the summit of Pico mountain $(2.2 \mathrm{~km}$ above sea level) in the Azores Islands, Portugal $\left(38.47^{\circ} \mathrm{N}, 28.40^{\circ} \mathrm{W}\right)$. During all seasons, the station is well above the regional marine boundary layer, which is typically less than $1 \mathrm{~km}$ in height from May to September and less than $1.4 \mathrm{~km}$ from October to April [Kleissl et al., 2007]. Upslope flow can bring air from lower altitudes to the station, including occasionally from the marine BL. However, upslope flow affects the Pico Mountain station much less than it does many other mountain observatories [Kleissl et al., 2007]. Impacts of upslope flow on nitrogen oxides, $\mathrm{CO}$ and $\mathrm{O}_{3}$ are small [Kleissl et al., 2007], indicating that the air sampled at the site is usually negligibly influenced by island pollution or the marine BL. The results obtained in this study are consistent with this expectation. For example, in periods with potential mechanical and/or buoyant upslope flow, median $\mathrm{NO}_{x}$ was 31 pptv, whereas it was 28 pptv during nonupslope flow periods.

\subsection{Measurements}

[11] $\mathrm{NO}, \mathrm{NO}_{2}$, and $\mathrm{NO}_{y}$ were determined by an automated $\mathrm{NO}_{x, y}$ system, which used established techniques for high sensitivity detection: $\mathrm{NO}$ detection by $\mathrm{O}_{3}$ chemiluminescence [Ridley and Grahek, 1990], $\mathrm{NO}_{2}$ by conversion to NO via ultraviolet photodissociation [Kley and McFarland, 1980; Parrish et al., 1990], and $\mathrm{NO}_{y}$ by Au-catalyzed reduction to $\mathrm{NO}$ in the presence of $\mathrm{CO}$ [Bollinger et al., 1983; Fahey et al., 1985]. A detailed description of the $\mathrm{NO}_{x, y}$ system including operation, sensitivities, conversion efficiencies, precision and artifacts can be found in the work of Val Martin et al. [2006].

[12] Measurements were recorded as 30-s averages (NO and $\left.\mathrm{NO}_{2}\right)$ and 20 -s averages $\left(\mathrm{NO}_{y}\right)$ every $10 \mathrm{~min}$, and further averaged to obtain the 30 -min averages used in this work. The instrumental detection limit $(2 \sigma)$ of the 30 -min averages is based on the artifact correction uncertainty and the precision $(2 \sigma)$ of the instrument. Detection limits were calculated separately for each individual measurement, on the basis of the standard deviation of 1-s photon counts. During the 3-year measurement campaign, the detection limit was 6.5 to 16 pptv for $\mathrm{NO}, 13$ to $17 \mathrm{pptv}$ for $\mathrm{NO}_{2}, 14$ to $21 \mathrm{pptv}$ for $\mathrm{NO}_{x}$ and 7.5 to $21 \mathrm{pptv}$ for $\mathrm{NO}_{y}$. (Reported median and maximum detection limit values.) These values were not constant because of occasional changes to instru- 
ment components and operation. Ninety percent of the measurements had detection limits less than 6.5 pptv for $\mathrm{NO}, 16$ pptv for $\mathrm{NO}_{2}$ and $\mathrm{NO}_{x}$, and 19 pptv for $\mathrm{NO}_{y}$. Measurement accuracy of $\mathrm{NO}$ and $\mathrm{NO}_{2}$ is estimated to be 5\% (20 July 2002 through 17 July 2003), 7\% (17 July 2003 through 1 May 2004) and 4\% (1 May 2004 through 25 August 2005) on the basis of total uncertainty of the sample and calibration mass flow controllers and the NO standard calibration gas mixing ratio.

[13] Accuracy of the $\mathrm{NO}_{y}$ measurements depends on the effective conversion of $\mathrm{NO}_{y}$ compounds, the lack of significant conversion of non-NO $\mathrm{NO}_{y}$ compounds [Fahey et al., 1985; Kliner et al., 1997; Kondo et al., 1997] and the uncertainty in the determination of the $\mathrm{NO}_{y}$ sensitivity, in addition to the accurate determination of the resulting NO. On the basis of regular calibrations and standard addition tests with $\mathrm{NO}_{2}$, i-propyl nitrate and $\mathrm{HNO}_{3}$ in ambient air, measured conversion efficiencies were $80-100 \%$ for $\mathrm{NO}_{2}$ (typically $>97 \%$ ), with similar values expected for PAN [Fahey et al., 1985], 62-100\% for $\mathrm{HNO}_{3}$ (typically $>80 \%$ ), and $61-100 \%$ for i-propyl nitrate (typically $>80 \%$ ). Because of occasional degradation of the $\mathrm{NO}_{y}$ converter, measurements of $\mathrm{NO}_{y}$ were corrected for nonunity $\mathrm{NO}_{y}$ conversion by using the $\mathrm{NO}_{2}$ conversion efficiencies measured at the system. In addition, $\mathrm{NO}_{y}$ observations in March-May 2003 and May-June 2004 presented an additional uncertainty of $13 \%$ and $5 \%$ because of uncertainty in the $\mathrm{NO}_{y}$ sensitivity determination, respectively. A maximum correction of $20 \%$ was applied to a few of the measurements made before March 2003 and a maximum correction of $8 \%$ was applied to measurements made from mid-July to mid-August 2004. No correction was made after mid-August 2004 as the $\mathrm{NO}_{2}$ conversion efficiency was constant to the expected range of $97-100 \%$.

[14] On the basis of the $\mathrm{NO}_{y}$ composition estimated at the Pico Mountain station (section 3.3.1) and the uncertainty of NO determination, total measured $\mathrm{NO}_{y}$ uncertainty was $\$ 20 \%$ at $\mathrm{NO}_{y}$ levels of 100 pptv and $\lesssim 15 \%$ at $\mathrm{NO}_{y}$ levels of $500 \mathrm{pptv}$, with the exception of the period from March to May 2003. During this period (less than 3\% of the total data set), total $\mathrm{NO}_{y}$ uncertainty was estimated to be at worst $\sim 55 \%$ at $\mathrm{NO}_{y}$ levels of 100 pptv, mainly because of potentially incomplete conversion to NO. These total measured uncertainties were calculated using propagation of errors of all source of errors. Interference of non- $\mathrm{NO}_{y}$ species was not a problem in this study as inferred from the very low conversion efficiencies (always less than $0.5 \%$; typically $0.3 \%$ ) during regular testing using standard addition of $\mathrm{CH}_{3} \mathrm{CN}$.

[15] As discussed by Val Martin et al. [2006], unexpected spikes were sometimes observed in ambient $\mathrm{NO}_{x}$ and $\mathrm{NO}_{y}$, and were attributed to volcanic emanations. To avoid including these observations in our analysis, we used methods similar to but slightly more stringent than those used previously [Val Martin et al., 2006]. (Additional information of the screening procedure and percentage of the data affected can be found in Val Martin et al. [2006] and Val Martin [2007].)

[16] In remote regions without significant biogenic $\mathrm{NO}_{x}$ emissions, nighttime NO values are expected to be zero because of the rapid oxidation of $\mathrm{NO}$ by $\mathrm{O}_{3}$ and the expected absence of local sources [Ridley et al., 1998;
Peterson et al., 1998]. This was true for all seasons, with the exception of summer 2004, which presented a nighttime median of 3 pptv. It was not possible to conclusively determine the reason for the generally nonzero nighttime NO levels during summer 2004. However, the weather at Pico that summer was unusual since it was dominated by high relative humidity $(\mathrm{RH})$ and calm wind periods. This may have resulted in a very small but detectable flux of NO from soil bacteria around the station. These nonzero nighttime NO observations could not be removed by any screening criterion attempted and systematically affected the measurements during this season. These emissions would presumably affect $\mathrm{NO}$ during the daytime and $\mathrm{NO}_{x}$ both day and night as well. However, the interference from this source does not appear to significantly affect the results: if we exclude the 2004 NO summertime observations, the diurnal cycle and seasonal variation presented below do not significantly change. For example, summer daytime median NO was 7.9 pptv in 2002-2005, whereas it was 7.7 pptv excluding the summer 2004 data set.

[17] Finally, during some sunny summer periods the temperature of the $\mathrm{NO}_{2}$ converter system increased to the extent that PAN decomposition could have produced a detectable positive bias in the $\mathrm{NO}_{2}$ measurements. At the maximum temperature recorded in the $\mathrm{NO}_{2}$ converter system $\left(39^{\circ} \mathrm{C}\right)$, up to about $2-4$ pptv $\mathrm{NO}_{2}$ could have been produced during the $\sim 8$ second residence time in the $\mathrm{NO}_{2}$ converter. This small interference may have contributed to the apparent daytime $\mathrm{NO}_{2}$ source described below, at least during summer and early fall.

[18] We also analyzed measurements of $\mathrm{CO}$ made from July 2002 to August 2005. The CO measurement methods are described in detail elsewhere [Owen et al., 2006; Honrath et al., 2004].

\subsection{GEOS-Chem and FLEXPART Simulations}

[19] Simulations of the global chemical transport model GEOS-Chem were conducted for comparison with the observations. GEOS-Chem version 7.01 was driven by assimilated meteorological fields from the Goddard Earth Observing System of NASA [Bey et al., 2001]. The spatial resolution of the model was $2^{\circ}$ latitude by $2.5^{\circ}$ longitude with 26 levels between the surface to $0.1 \mathrm{hPa}$. Global anthropogenic emissions were determined following the procedure described by Bey et al. [2001]. Over the continental United States and Europe, the anthropogenic emissions were based on the United States Environmental Protection Agency (EPA) National Emission Inventory-97 $[E P A, 1997]$ and the European Monitoring and Evaluation Program (EMEP) for European countries [European Monitoring and Evaluation Program, 1997]. Biomass burning emissions were obtained from Duncan et al. [2003] with monthly mean estimates relocated using ModerateResolution Imaging Spectroradiometer fire counts. More information on these emissions and additional sources (e.g., lightning, stratospheric injection) is presented elsewhere [Bey et al., 2001].

[20] To evaluate the sensitivity of our measurements to stratospheric transport, we used the FLEXPART particle dispersion model version 6.2 [Stohl, 1998; Stohl et al., 2005]. FLEXPART was driven with data from the European Center for Medium-Range Weather Forecasts [2005] with a 

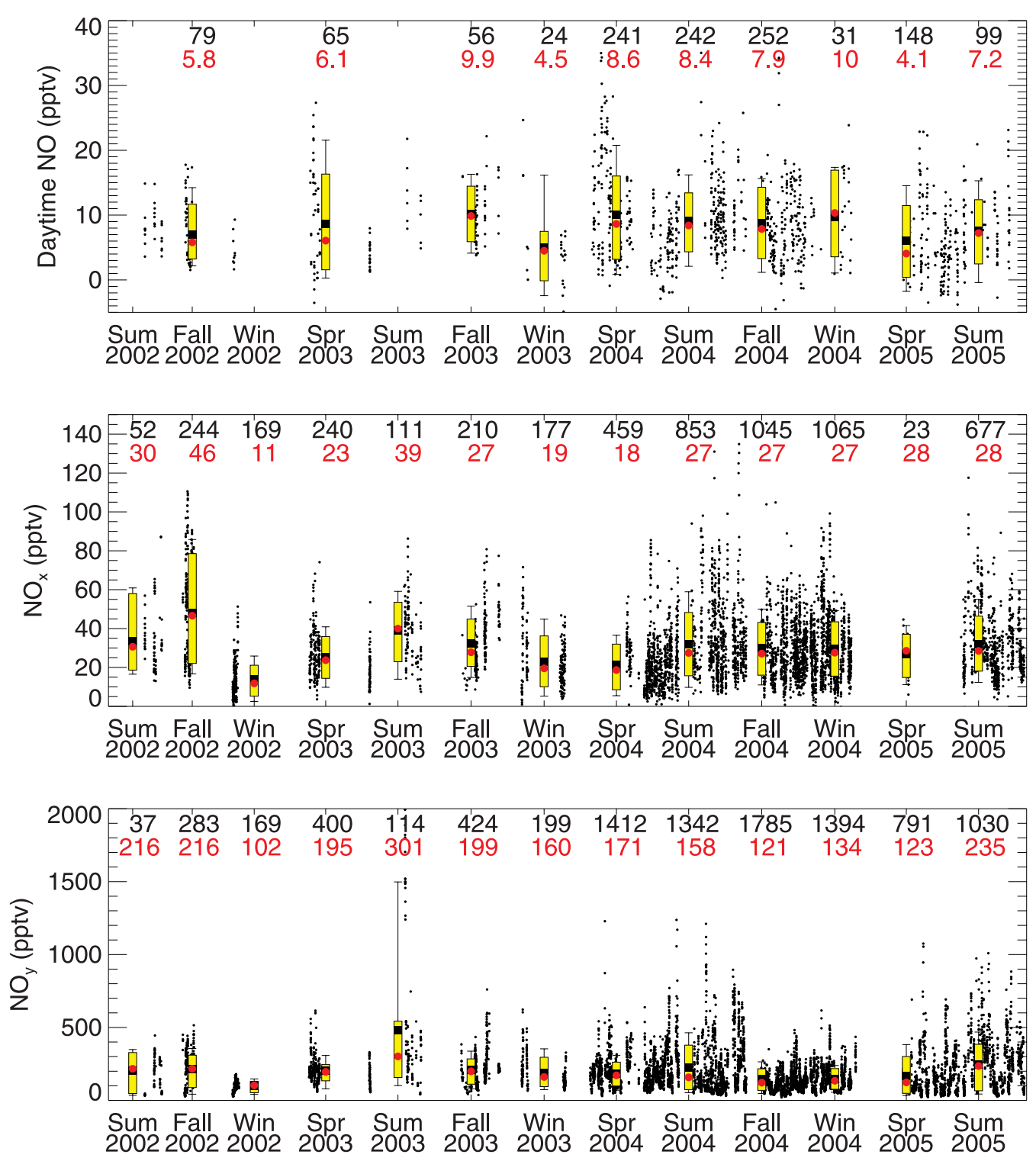

Figure 1. Time series of (top) daytime $\mathrm{NO}$, (middle) $\mathrm{NO}_{x}$, and (bottom) $\mathrm{NO}_{y}$ at the Pico Mountain station. Daytime NO data are observed when the solar zenith angle was below $62^{\circ}$ (see text for explanation). Each data point represents a 30-min average. Bar plots indicate the distribution of the data for each season and year. The medians (red circles) and the means (black squares) are shown along with the central 67\% (yellow box) and the central 95\% (thin black lines). The number of 30-min average measurements (black numbers) and the median (red numbers) included in each distribution are given above the plot for each bar. Distributions with fewer than 20 data points are not shown. Discontinuity on the data is due to Pico Mountain station shutdowns and periods of maintenance and/or malfunctioning of the $\mathrm{NO}_{x, y}$ system.

$1^{\circ} \times 1^{\circ}$ horizontal resolution, 60 vertical levels and a temporal resolution of three hours, using meteorological analyses at 0000, 0600, 1200, and 1800 UTC, and European Center for Medium-Range Weather Forecasts (ECMWF) 3-h forecasts at 0300, 0900, 1500, and 2100 UTC. We ran FLEXPART in its forward mode to simulate the transport of a stratospheric $\mathrm{O}_{3}$ tracer. This was done by releasing particles, which represent infinitesimally small air parcels, in the lower stratosphere. Each particle carried a mass of ozone determined by the potential vorticity (PV) at the particles initial location and release time. Particles released where PV was greater than $2.0 \mathrm{pvu}$ were given a specific mass according to $\mathrm{M}_{\mathrm{O}_{3}}=\mathrm{M}_{\text {air }} \times \mathrm{PV} \times \mathrm{C}$, where $\mathrm{M}_{\text {air }}$ was the mass of air represented by a particle and $\mathrm{C}=60 \times 10^{-9} \mathrm{pvu}^{-1}$ was the ozone/PV relationship [Stohl et al., 2000]. Particles were then allowed to advect through the stratosphere and into the troposphere according to the winds. At any one time, approximately 4 million particles were present in the model for these stratospheric tracer runs. Particles were carried in the model for 20 days before being removed. This tracer is referred to here as FLEXPART Strat- $\mathrm{O}_{3}$.

\section{Results and Discussion}

[21] Figure 1 presents an overview of the nitrogen oxides measurements at the Pico Mountain station from July 2002 
Table 1. Statistical Parameters of the Nitrogen Oxides Diurnal Cycle ${ }^{\mathrm{a}}$

\begin{tabular}{|c|c|c|c|c|c|c|c|c|c|}
\hline \multirow[b]{2}{*}{ Season $^{\mathrm{d}}$} & \multirow[b]{2}{*}{ Data } & \multicolumn{3}{|c|}{ Daytime $^{\mathrm{b}}$} & \multicolumn{3}{|c|}{ Nighttime $^{\mathrm{b}}$} & \multicolumn{2}{|c|}{ Amplitude $^{\mathrm{c}}$} \\
\hline & & Mean \pm SD & Median & $\mathrm{N}$ & Mean \pm SD & Median & $\mathrm{N}$ & $\Delta$ Mean & $\Delta$ Median \\
\hline Spring & NO & $9 \pm 8$ & 7 & 454 & $1 \pm 3$ & 0 & 889 & $8 \pm 2$ & 6 \\
\hline Spring & $\mathrm{NO}: \mathrm{NO}_{2}$ & $0.4 \pm 0.5$ & 0.3 & 89 & $0.1 \pm 0.4$ & 0.0 & 277 & $0.3 \pm 0.2$ & 0.3 \\
\hline Spring & $\mathrm{NO}_{2}$ & $21 \pm 11$ & 21 & 148 & $19 \pm 11$ & 18 & 308 & $2 \pm 4$ & 3 \\
\hline Spring & $\mathrm{NO}_{x}$ & $29 \pm 16$ & 26 & 124 & $20 \pm 11$ & 18 & 322 & $9 \pm 6$ & 8 \\
\hline Spring & $\mathrm{NO}_{y}$ & $184 \pm 123$ & 178 & 704 & $184 \pm 111$ & 166 & 905 & $0 \pm 24$ & 12 \\
\hline Summer & NO & $9 \pm 5$ & 8 & 369 & $2 \pm 4$ & 2 & 947 & $7 \pm 1$ & 6 \\
\hline Summer & $\mathrm{NO}: \mathrm{NO}_{2}$ & $0.4 \pm 0.3$ & 0.3 & 236 & $0.1 \pm 0.3$ & 0.0 & 660 & $0.3 \pm 0.1$ & 0.3 \\
\hline Summer & $\mathrm{NO}_{2}$ & $25 \pm 13$ & 23 & 296 & $28 \pm 16$ & 25 & 740 & $-3 \pm 4$ & -2 \\
\hline Summer & $\mathrm{NO}_{x}$ & $37 \pm 18$ & 33 & 323 & $31 \pm 16$ & 26 & 781 & $6 \pm 5$ & 7 \\
\hline Summer & $\mathrm{NO}_{y}$ & $222 \pm 180$ & 165 & 542 & $247 \pm 208$ & 201 & 1099 & $-25 \pm 40$ & -36 \\
\hline Fall & NO & $9 \pm 5$ & 8 & 387 & $1 \pm 3$ & 0 & 660 & $8 \pm 1$ & 8 \\
\hline Fall & $\mathrm{NO}: \mathrm{NO}_{2}$ & $0.3 \pm 0.2$ & 0.3 & 265 & $0.0 \pm 0.1$ & 0.0 & 415 & $0.3 \pm 0.1$ & 0.3 \\
\hline Fall & $\mathrm{NO}_{2}$ & $28 \pm 16$ & 24 & 297 & $30 \pm 17$ & 26 & 452 & $-2 \pm 5$ & -2 \\
\hline Fall & $\mathrm{NO}_{x}$ & $36 \pm 20$ & 31 & 294 & $31 \pm 16$ & 26 & 458 & $5 \pm 6$ & 5 \\
\hline Fall & $\mathrm{NO}_{y}$ & $160 \pm 102$ & 141 & 511 & $163 \pm 108$ & 134 & 738 & $-3 \pm 24$ & 7 \\
\hline Winter & NO & $7 \pm 6$ & 5 & 64 & $0 \pm 2$ & 0 & 562 & $7 \pm 3$ & 5 \\
\hline Winter & $\mathrm{NO}: \mathrm{NO}_{2}$ & $0.4 \pm 0.3$ & 0.4 & 40 & $0.0 \pm 0.2$ & 0.0 & 447 & $0.4 \pm 0.2$ & 0.4 \\
\hline Winter & $\mathrm{NO}_{2}$ & $24 \pm 13$ & 24 & 50 & $25 \pm 16$ & 23 & 462 & $-1 \pm 8$ & 1 \\
\hline Winter & $\mathrm{NO}_{x}$ & $26 \pm 14$ & 23 & 49 & $24 \pm 14$ & 22 & 441 & $2 \pm 9$ & 1 \\
\hline Winter & $\mathrm{NO}_{v}$ & $156 \pm 79$ & 145 & 76 & $152 \pm 88$ & 128 & 512 & $4 \pm 39$ & 17 \\
\hline
\end{tabular}

${ }^{\mathrm{a}}$ Reported average, standard deviation (SD), median, and number $(\mathrm{N})$ of the 30 -min average observations in $\mathrm{pptv}$ for $\mathrm{NO}, \mathrm{NO}_{2}, \mathrm{NO}_{x}$, and $\mathrm{NO}_{y}$.

${ }^{\mathrm{b}}$ Daytime values are observations when the solar zenith angle was $<62^{\circ}$ and nighttime values are observations between $2300-0500 \mathrm{UTC}$.

${ }^{\mathrm{c}}$ Amplitude is expressed as the difference between the means ( $\Delta$ Mean) and the medians $(\Delta$ Median) of daytime and nighttime. Uncertainty $(2 \sigma)$ is based on propagation of errors.

${ }^{d}$ Seasons are as follows: spring is March, April, and May; summer is June, July, and August; fall is September, October, and November; and winter is December, January, and February.

to August 2005. All 30-min averages of daytime $\mathrm{NO}, \mathrm{NO}_{x}$, and $\mathrm{NO}_{y}$ are shown as time series, and bar plots represent the distribution of the data by season and year.

[22] Significant variability is apparent in the data at all times of the year. A large number of factors contribute to the magnitude and the changes of the nitrogen oxides levels. In this section, three aspects of the data are analyzed: diurnal cycles, seasonal variation and partitioning of $\mathrm{NO}_{y}$. These aspects are not entirely independent but provide a structure for discussion.

\subsection{Diurnal Cycles}

[23] Diurnal cycles of nitrogen oxides can be caused by photochemical, transport and emission processes whose strength vary between day and night. Table 1 summarizes the statistical parameters of the diurnal cycles of $\mathrm{NO},[\mathrm{NO}] /$ $\left[\mathrm{NO}_{2}\right], \mathrm{NO}_{2}, \mathrm{NO}_{x}$, and $\mathrm{NO}_{y}$ for each season. As an example, Figure 2 displays the diurnal variation for the springtime measurements of $\mathrm{NO},[\mathrm{NO}] /\left[\mathrm{NO}_{2}\right], \mathrm{NO}_{2}$, and $\mathrm{NO}_{y}$. (Similar variation was present in the other seasons.) Negative values are shown in Figures $2 a$ and $2 b$ to indicate the scatter of the individual measurements, which is due to measurement imprecision; the true atmospheric mixing ratios are of course never negative. For the $[\mathrm{NO}] /\left[\mathrm{NO}_{2}\right]$ analysis, values that deviated from the mean by more than three times the standard deviation were removed. This was done because $\mathrm{NO}_{2}$ and $\mathrm{NO}$ measurements are related as the calculation of $\mathrm{NO}_{2}$ includes the $\mathrm{NO}$ mixing ratio. Hence, rare outliers in the $\mathrm{NO}$ measurements may result in $\mathrm{NO}_{2}$ outliers, which produces unrealistic $[\mathrm{NO}] /\left[\mathrm{NO}_{2}\right]$ values that may significantly affect the mean [Yang et al., 2002].

[24] To test for the existence of a consistent diurnal variation, we examined both the median and the mean of the data in the nighttime and daytime subsets. Nighttime
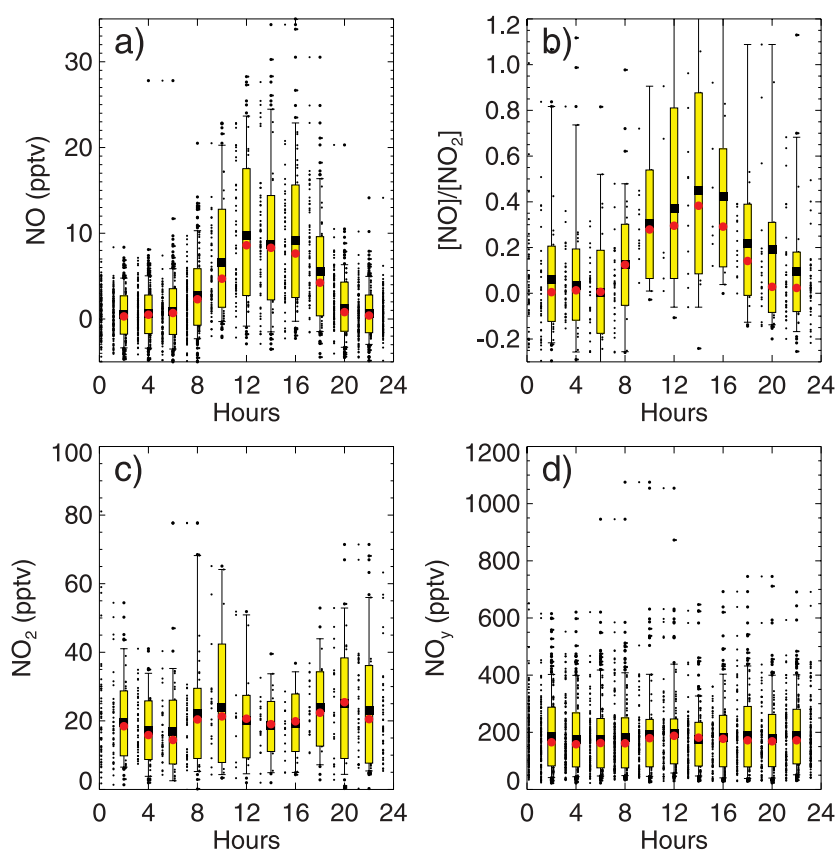

Figure 2. Springtime diurnal cycles of (a) $\mathrm{NO}$, (b) [NO]/ $\left[\mathrm{NO}_{2}\right]$, (c) $\mathrm{NO}_{2}$, and (d) $\mathrm{NO}_{y}$. All 30-min average data, with the exception of $[\mathrm{NO}] /\left[\mathrm{NO}_{2}\right]$ (see text for explanation), are plotted at the nearest hour. A few data points outside the plot boundaries are not shown to make the cycle more apparent $\left(25\right.$ for $\mathrm{NO}$ and $\mathrm{NO} / \mathrm{NO}_{2}, 8$ for $\mathrm{NO}_{2}$, and 1 for $\mathrm{NO}_{y}$ ). Bar plots indicate the distribution of the data in each 2-h intervals. The medians (red circles) and the means (black squares) are shown along with the central 67\% (yellow box) and the central 95\% (thin black lines). 
values were observations made between 2300 and 0500 UTC; daytime values were those made when the solar zenith angle was below $62^{\circ}$. These cutoffs were chosen to allow significant numbers of data points in both subsets while providing daylight and nighttime conditions in all seasons. As expected, Table 1 indicates that robust diurnal cycles exist for $\mathrm{NO}$ and $[\mathrm{NO}] /\left[\mathrm{NO}_{2}\right]$ ratios in all seasons, with median diurnal amplitudes of $5-8$ pptv and $0.3-0.4$, respectively. The phase of these cycles is consistent with photochemical causes: the maximum occurs around the time of maximum insolation at local solar noon (1400 UTC for spring; Figure 2), indicating a dominance of production of NO from photolysis of $\mathrm{NO}_{2}$, whereas the minimum occurs at nighttime, indicating dominance of $\mathrm{NO}$ destruction by reaction with $\mathrm{O}_{3}$.

[25] Given the observed NO cycle amplitude, a negative amplitude of similar magnitude should be present in the $\mathrm{NO}_{2}$ cycle as $\mathrm{NO}_{2}$ is photolyzed to $\mathrm{NO}$ during daytime. Figure $2 \mathrm{c}$ and Table 1 indicate that a very weak negative diurnal variation or no variation was present for $\mathrm{NO}_{2}$, with median diurnal amplitudes of -2 to 3 pptv. This small negative or nonexistent amplitude suggests the presence of a small source of $\mathrm{NO}_{2}$ during daytime. As discussed in section 2, this may be partially the result of interference of PAN decomposition in the photolysis cell during summer and early fall. The absence of a negative or no diurnal variation of $\mathrm{NO}_{2}$ results in the presence of a diurnal cycle for $\mathrm{NO}_{x}$ from spring to fall, with median amplitudes of 5 to 8 pptv (Table 1).

[26] Consistent with our expectation that diurnally varying upslope flow does not affect the measurements [Kleissl et al., 2007], Figure 2d and Table 1 show that no significant diurnal variation was present for $\mathrm{NO}_{y}$, with the exception of the summer, which exhibited a negative median amplitude of $36 \mathrm{pptv}$. This may be due to rapid removal of summertime $\mathrm{NO}_{y}$, which is primarily composed of $\mathrm{HNO}_{3}$, as estimated below in section 3.3.1. Summertime RH measurements at the Pico Mountain station indicate that the percentage of $\mathrm{NO}_{y}$ observations made in the presence of clouds (RH above $96 \%$, section 3.3.1) was larger during the daytime $(24 \%)$ than at nighttime $(16 \%)$, which may result in a stronger wet removal of $\mathrm{HNO}_{3}$ during the day.

[27] Comparisons of the diurnal variation observed at the Pico Mountain station to those observed at other remote marine FT stations are not straightforward. As opposed to the Pico Mountain station, ground-based mountaintop stations (e.g., Mauna Loa Observatory (MLO) over the North Pacific Ocean and Izaña over the eastern Atlantic Ocean) are typically characterized by a diurnal downslopeupslope flow regime [Ridley et al., 1998; Fischer et al., 1998]. However, spring diurnal amplitudes of $\sim 8$ pptv for $\mathrm{NO}$ and $\sim 0.4$ for $\mathrm{NO} / \mathrm{NO}_{2}$ were observed at MLO during a rare event in which free tropospheric air was sampled all day [Ridley et al., 1998], similar to the spring amplitude observed at the Pico Mountain station for NO (8 \pm 2 pptv) and for $[\mathrm{NO}] /\left[\mathrm{NO}_{2}\right](0.3 \pm 0.2)$.

\subsection{Seasonal Variation}

[28] In this section, we first determine the seasonal variation of nitrogen oxides on a monthly basis. Second, we compare the mixing ratios of nitrogen oxides at the Pico Mountain station with observations from previous studies.

\subsubsection{Annual Cycle}

[29] Figures $3 a-3 c$ present the annual cycle of nitrogen oxides at the Pico Mountain station. All years are included, and the monthly medians in each year (e.g., April 2002 and March 2003) are indicated with horizontal blue lines within each bar and numerals to the right of each bar. Nighttime $\mathrm{NO}$ is not shown in Figure $3 \mathrm{~b}$ since values are zero, as explained above in section 2. For $\mathrm{NO}_{y}$, Figure $3 \mathrm{c}$ shows the seasonal cycle determined when dry conditions were present (RH below 60\%). (Lower $\mathrm{NO}_{y}$ levels were observed when RH was high, because of removal into fog droplets at the measurement site, as discussed further in section 3.3.1. Thus, $\mathrm{NO}_{y}$ observations in dry conditions are a better representation of $\mathrm{NO}_{y}$ levels in the North Atlantic lower FT.) In Figure 3d, the annual cycle of $\mathrm{CO}$ is also shown for comparison. The monthly statistics plotted in Figure 3 are available in the work of Val Martin [2007]. It is clear from Figures $3 a-3 d$ that during some months the monthly medians varied substantially from year to year. Large variability of $\mathrm{CO}$ at hemispheric scales is known to occur, and has mainly been associated with variations in biomass burning emissions [e.g., Novelli et al., 2003; Edwards et al., 2004; Honrath et al., 2004]. Although interannual variability is also apparent for the nitrogen oxides, we find that in some cases this variability may be due to the limited number of observations available and the fact that transport events result in large standard deviations within each month. For example, median $\mathrm{NO}_{x}$ in October 2002 was much higher (47 pptv) than in 2003 (27 pptv) and 2004 (25 pptv) because $\mathrm{NO}_{x}$ observations were only available for about 10 days in 2002, which happened to coincide with two North American outflow events.

[30] Figure 3d shows a sharp seasonal cycle for $\mathrm{CO}$, with a minimum median of 90 ppbv in July-August and a maximum median of $146 \mathrm{ppbv}$ in March. CO is oxidized by $\mathrm{OH}$, and the annual variation of $\mathrm{CO}$ is driven to a large extent by the annual cycle of $\mathrm{OH}$, which is closely related to the water vapor and the solar intensity cycle [Novelli et al., 1992]. In addition to photochemical processes, seasonal variation in synoptic flow patterns, and the associated changes in source regions and transport times to the measurement site can also affect background levels of $\mathrm{CO}$. On the basis of a clustering analysis of backward trajectories to the Pico Mountain station (J. Strane et al., Major source regions to the Pico Mountain station: Transport, chemical observations, and interannual variability, manuscript in preparation, 2008), more frequent transport from the Atlantic basin and longer transit times from the North American continent in summer may also explain the lower observed summertime CO. The annual variation of inferred $\mathrm{OH}$ concentrations and transport patterns was also noted to modulate the nonmethane hydrocarbons (NMHC) sampled at the Pico Mountain station [Helmig et al., 2008].

[31] In contrast to $\mathrm{CO}$, the seasonal variation of nitrogen oxides is more complex. The variation of nitrogen oxides in the troposphere remote from sources of $\mathrm{NO}_{x}$ depends largely on the partitioning of $\mathrm{NO}_{y}$ [e.g., Atlas et al., 1992; Ridley et al., 1998], which in turn, is controlled to a large extent by the rate of loss of the reservoir species and by the recycling of $\mathrm{NO}_{x}$ from these reservoirs. Moreover, since the loss processes differ among compounds, each process may result in a different effect on $\mathrm{NO}_{y}$. For example, thermal 

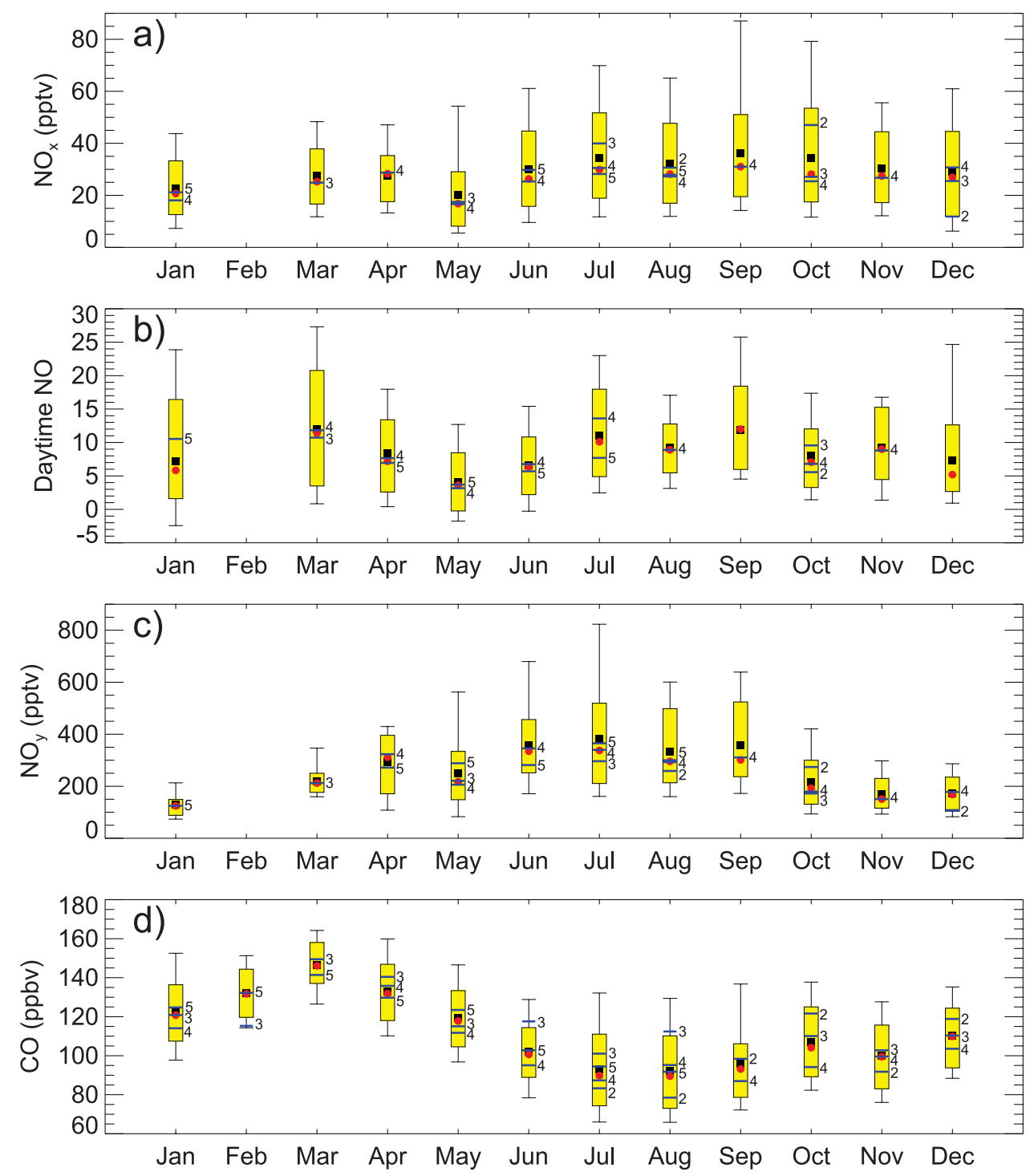

Figure 3. Seasonal cycle of (a) $\mathrm{NO}_{x}$, (b) daytime $\mathrm{NO}$, and (c) $\mathrm{NO}_{y}$ in dry conditions (see text for explanation), and (d) CO. Bar plots indicate the distribution of the data for each month, independent of the year of measurement. The medians (red circles) and the means (black squares) are shown along with the central 67\% (yellow box) and the central 95\% (thin black lines). Months with fewer than 20 data points are not shown. The median for all observations in each month and year are plotted by horizontal blue lines within each bar; numerals to the right of the bar plots indicate the year of each monthly median (where 2 is the year 2002, 3 is the year 2003, 4 is the year 2004, and 5 is the year 2005). Medians with fewer than 20 data points are not shown.

decomposition of PAN regenerates $\mathrm{NO}_{2}$, which changes the partitioning of $\mathrm{NO}_{y}$ but not total $\mathrm{NO}_{y}$, whereas wet and dry deposition of $\mathrm{HNO}_{3}$ results in a change in total $\mathrm{NO}_{y}$ as nitrogen is removed from the atmosphere.

[32] Figure 3a shows that $\mathrm{NO}_{x}$ observations exhibited a distinct seasonal cycle in the overall variability, with all percentiles larger from July to October than in the other months. However, monthly medians did not reveal a clear pattern. Similar monthly medians were present all yearround (17-31 pptv). (To avoid the possible interference from a small daytime bias in $\mathrm{NO}_{2}$ during some summer periods (section 3.1), we also compared nighttime $\mathrm{NO}_{x}$ medians and found similar results: $16-28 \mathrm{pptv})$. Because the lifetime of $\mathrm{NO}_{x}$ in the lower FT (on the order of $\lesssim 1$ day
[Liu et al., 1987]) is shorter than the transit time from $\mathrm{NO}_{x}$ source regions to the measurement site, it is clear that in situ sources of $\mathrm{NO}_{x}$ are required to provide these $\mathrm{NO}_{x}$ levels all year-round. This implies that PAN decomposition and potentially photolysis of $\mathrm{HNO}_{3}$ in the air masses that reach the Pico Mountain station provide a supply of $\mathrm{NO}_{x}$ to the lower FT in this region, in particular during summer seasons.

[33] Because of the rapidly increasing solar insolation and decreasing $\mathrm{O}_{3}$ concentrations from spring to fall, one may expect a shift of $\mathrm{NO}_{x}$ partition toward $\mathrm{NO}$ as photolysis of $\mathrm{NO}_{2}$ increases and the rate of the reaction of $\mathrm{NO}$ with $\mathrm{O}_{3}$ decreases. However, the actual situation was different. Figure $3 \mathrm{~b}$ shows that daytime NO mixing ratios exhibited 
a small broad peak from July to September, with medians of 9-12 pptv. The increase in NO during these months is consistent with the increase in solar radiation and generally lower $\mathrm{O}_{3}$ mixing ratios observed at the Pico Mountain station (not shown). However, a peak was also present in March, with a median of 11 pptv. The cause of this peak is not understood.

[34] As shown in Figure 3c, $\mathrm{NO}_{y}$ observations exhibited a well-defined seasonal cycle, with larger medians in JuneSeptember (296-338 pptv) than in November-March (125-212 pptv). There are several processes that may contribute to this behavior.

[35] First, as shown in a more detailed specific event-toevent study, there appears to be a greater export and transport of nitrogen oxides from the North American BL to the Pico Mountain site during the summer season [ Val Martin et al., 2008]. Parrish et al. [2004] proposed that shallow venting of the continental BL to the lower FT, driven by surface heating and associated with fair weather cumulus breaking through the afternoon BL, may provide an important lofting mechanism for anthropogenic emissions over the eastern United States. This mechanism, which is expected to be most frequent in summer, may result in a significant export of nitrogen oxides to the North Atlantic region [Parrish et al., 2004; Li et al., 2004; Hudman et al., 2007].

[36] Second, boreal wildfires have been recently recognized to be a significant source of nitrogen oxides to the North Atlantic troposphere [Val Martin et al., 2006; Singh et al., 2007]. $\mathrm{NO}_{y}$ means from July to September (typically the boreal fire season) exceeded the medians by $13-18 \%$, showing extreme excursions from the median in the positive direction. The higher variability of $\mathrm{NO}_{y}$ in these months reflects the high but varying influence of boreal wildfire emissions [Val Martin et al., 2008]. Thus, summertime wildfire emissions result in higher levels of $\mathrm{NO}_{y}$.

[37] Finally, variation in the input from stratospheric or upper tropospheric sources could also contribute to changes in nitrogen oxides. $\mathrm{NO}_{x}$ production by lightning varies seasonally, with the maximum production occurring in the Northern Hemisphere during summer [Nesbitt et al., 2000]. Stratospheric injection is found to be more important during springtime [e.g., Parrish and Fehsenfeld, 2000; Merrill and Moody, 1996], although injections are also frequent in summer [Thompson et al., 2007]. To assess the impact of stratospheric and upper tropospheric transport to the Pico Mountain station, we used FLEXPART Strat-O $_{3}$ values from July 2002 to August 2005. This analysis indicated that stratospheric $\mathrm{O}_{3}$ occasionally impacts the measurement site, but the overall impact is rather small: the average \pm 2 standard deviation of all FLEXPART Strat-O $\mathrm{O}_{3}$ values was $7 \pm 9$ ppbv, without significant variation on a seasonal basis. On an event basis, we did not find any consistent correlation between nitrogen oxides levels and FLEXPART Strat- $\mathrm{O}_{3}$, i.e., enhancements of $\mathrm{NO}_{y}$ were not correlated with increases in the FLEXPART Strat- $\mathrm{O}_{3}$ values. We thus conclude that stratospheric air did not significantly contribute to the changes in the nitrogen oxides observed at the Pico Mountain station.

\subsubsection{Comparison to Previous Measurements}

[38] Table 2 compares the mixing ratios of nitrogen oxides at the Pico Mountain station with observations from previous aircraft studies in the North Atlantic troposphere and from two ground-based stations, MLO over the North Pacific Ocean and Jungfraujoch (JFJ) station over central Europe. Values are compiled by seasons. The majority of these studies were made during the summer season. Thus, we focus here on summertime observations, unless indicated otherwise.

[39] It is evident that nitrogen oxides levels at the Pico Mountain station (median 322 pptv for $\mathrm{NO}_{y}$ and 29 pptv for $\mathrm{NO}_{x}$; Table 2 rows 2 and 14) are lower than those observed in other studies over the western North Atlantic at $0.5-6 \mathrm{~km}$ altitudes $\left(652-1480\right.$ pptv for $\mathrm{NO}_{y}$ and $40-55 \mathrm{pptv}$ for $\mathrm{NO}_{x}$; Table 2 rows $5-8,11$, and $17-20)$. $\mathrm{NO}_{x}$ and $\mathrm{NO}_{y}$ typically exhibit a $\mathrm{C}$-shaped profile above source regions, with high concentrations near the surface decreasing through the FT and then rising sharply at altitudes generally above $6 \mathrm{~km}$ [e.g., Singh et al., 2007]. This is the result of the combination of atmospheric oxidation with the location of the emissions (BL and upper troposphere) and convection. Lower $\mathrm{NO}_{y}$ and $\mathrm{NO}_{x}$ at the Pico Mountain station indicate that removal of $\mathrm{NO}_{y}$ and rapid oxidation of $\mathrm{NO}_{x}$ in the air masses may occur as a result of longer transport times over the ocean. In addition, lower $\mathrm{NO}_{y}$ and $\mathrm{NO}_{x}$ levels may also indicate a smaller influence of stratospheric and upper tropospheric sources at the Pico Mountain site as air is sampled at lower altitudes than that in the aircraft campaigns.

[40] Nitrogen oxides levels observed at MLO (median 168-374 pptv for $\mathrm{NO}_{y}$ and 25-36 pptv for $\mathrm{NO}_{x}$; Table 2 rows 3 and 15) were similar to those observed at the Pico Mountain station (147-322 pptv for $\mathrm{NO}_{y}$ and 21-29 pptv for $\mathrm{NO}_{x}$ ) all year round. Similar to the Pico Mountain station, MLO is a remote marine observatory, in which well-aged air masses are sampled during downslope conditions [Ridley et al., 1998]. Thus, observed levels at MLO also reflect the strong removal of $\mathrm{NO}_{y}$ and rapid oxidation of $\mathrm{NO}_{x}$ in the air masses during transport. In contrast, larger $\mathrm{NO}_{x}$ and $\mathrm{NO}_{y}$ medians present at the continental JFJ observatory (350-581 pptv for $\mathrm{NO}_{y}$ and 87-133 pptv for $\mathrm{NO}_{x}$; Table 2 rows 4 and 16) suggest the input of relatively fresh $\mathrm{NO}_{x}$ emissions from the continental BL [Zellweger et al., 2003].

\subsection{Average Partitioning of $\mathrm{NO}_{y}$}

[41] To better understand the changes on the nitrogen oxides over the central North Atlantic lower FT, we examined the partitioning of $\mathrm{NO}_{y}$ into its three principal components: $\mathrm{NO}_{x}, \mathrm{HNO}_{3}$, and PAN.

\subsubsection{Estimation of $\mathrm{NO}_{\boldsymbol{y}}$ Partitioning}

[42] $\mathrm{NO}_{y}$ partitioning was estimated using the $\mathrm{NO}_{x}$ and $\mathrm{NO}_{y}$ measurements in combination with station measurements of $\mathrm{RH}$, taking advantage of the fact that $\mathrm{HNO}_{3}$ removal occurs in local, orographic clouds on Pico Mountain. Several studies have demonstrated the rapid and efficient scavenging of nitric acid within clouds [e.g., Chameides, 1984; Peterson et al., 1998; Garrett et al., 2006]. For example, Chameides [1984] showed that $\mathrm{HNO}_{3}$ levels decreased by 2 orders of magnitude in less than 100 seconds after marine cloud formation. Consistent with those studies, $\mathrm{NO}_{y}$ levels at the Pico Mountain station were reduced in the presence of clouds as noted in section 3.2.1. Thus, measurements of $\mathrm{NO}_{y}$ levels during in-cloud and out- 
Table 2. Observation of Nitrogen Oxides in the Lower Free Troposphere of Remote Regions ${ }^{\mathrm{a}}$

\begin{tabular}{|c|c|c|c|c|c|c|c|c|c|c|c|}
\hline \multirow[b]{2}{*}{ Year } & \multirow{2}{*}{$\begin{array}{l}\text { Sampling } \\
\text { Location }^{\mathrm{b}}\end{array}$} & \multirow[b]{2}{*}{ Altitude $(\mathrm{km})$} & \multicolumn{2}{|c|}{ Spring } & \multicolumn{2}{|c|}{ Summer } & \multicolumn{2}{|c|}{ Fall } & \multicolumn{2}{|c|}{ Winter } & \multirow[b]{2}{*}{ Source } \\
\hline & & & Mean \pm SD & Median & Mean $\pm \mathrm{SD}$ & Median & Mean \pm SD & Median & Mean \pm SD & Median & \\
\hline $2002-2005^{\mathrm{d}}$ & C Atl & 2.2 & $257 \pm 115$ & 229 & $\begin{array}{l}N O_{y} \text { (pptv) } \\
358 \pm 160\end{array}$ & 322 & $228 \pm 121$ & 195 & $165 \pm 73$ & 147 & 1 \\
\hline $1991-1992$ & N Pac & 3.4 & $368 \pm 109$ & 374 & $203 \pm 99$ & 188 & $177 \pm 70$ & 168 & $204 \pm 82$ & $\begin{array}{l}187 \\
187\end{array}$ & 2 \\
\hline 1997-1999 & W Eur & 3.6 & $748 \pm 614$ & 581 & $653 \pm 570$ & 529 & $553 \pm 477$ & 422 & $501 \pm 659$ & 350 & 3 \\
\hline 2004 & W Atl & $2-4$ & - & - & $809 \pm 610$ & 652 & - & - & - & - & 4 \\
\hline $1996-1997$ & W Atl & $2-4$ & $545 \pm 74$ & 550 & - & - & $434 \pm 267$ & 377 & - & - & 5 \\
\hline $1988-1993$ & W Atl & $0.5-3$ & - & - & $817 \pm 104$ & 850 & - & - & $675 \pm 248$ & 675 & 6 \\
\hline $1988-1993$ & W Atl & $3-6$ & - & - & $969 \pm 65$ & 1000 & - & - & $467 \pm 76$ & 450 & 6 \\
\hline 1993 & C Atl & 1 & - & - & $495 \pm 214$ & 480 & - & - & - & - & 7 \\
\hline 1993 & E Atl & 2.4 & - & - & $390 \pm 100$ & 390 & - & - & - & - & 8 \\
\hline 1993 & W Atl & $0.8-6$ & - & - & $3520 \pm 4990$ & 1480 & - & - & - & - & 7 \\
\hline \multirow[t]{2}{*}{2000} & N Ame & $2-3$ & - & $275-450$ & - & - & - & - & - & $275-300$ & 9 \\
\hline & & & & & $N O_{x}(p p t v)$ & & & & & & \\
\hline $2002-2005$ & C Atl & 2.2 & $23 \pm 14$ & 21 & $32 \pm 17$ & 29 & $33 \pm 19$ & 28 & $27 \pm 16$ & 24 & 1 \\
\hline $1991-1992$ & N Pac & 3.4 & $39 \pm 15$ & 36 & $29 \pm 12$ & 28 & $26 \pm 9$ & 25 & $32 \pm 11$ & 31 & 2 \\
\hline 1997-1999 & W Eur & 3.6 & $183 \pm 289$ & 98 & $191 \pm 482$ & 133 & $205 \pm 355$ & 115 & $203 \pm 454$ & 87 & 3 \\
\hline 2004 & W Atl & $2-4$ & - & - & $64 \pm 63$ & 52 & - & - & - & - & 4 \\
\hline $1996-1997$ & W Atl & $2-4$ & $24 \pm 20$ & 23 & - & - & $26 \pm 22$ & 20 & - & - & 5 \\
\hline $1988-1993$ & W Atl & $0.5-3$ & - & - & $73 \pm 67$ & 40 & - & - & - & - & 6 \\
\hline $1988-1993$ & W Atl & $3-6$ & - & - & $55 \pm 21$ & 55 & - & - & - & 30 & 6 \\
\hline 1993 & E Atl & 2.4 & - & - & $50 \pm 20$ & 50 & - & - & - & - & 8 \\
\hline 2000 & N Ame & $2-3$ & - & $15-50$ & - & - & - & - & - & 28 & 9 \\
\hline
\end{tabular}

${ }^{\mathrm{a}}$ Dashes indicate that values are not reported.

${ }^{b} \mathrm{~N}$ Pac, North Pacific Ocean; N Ame, North America; W Atl, western North Atlantic Ocean; C Atl, central North Atlantic Ocean; E Atl, eastern North Atlantic Ocean; W Eur, western Europe.

${ }^{\mathrm{c} S}$ Sources are as follows: 1, Pico Mountain (this work); 2, MLO (B. Ridley, NCAR, United States, personal communication, 2007); 3, JFJ [Zellweger et al., 2003]; 4, ICARTT [Singh et al., 2007]; 5, NARE96 and NARE97 (D. Parrish, NOAA, United States, personal communication, 2007); 6, Emmons et al. [1997]; 7, NARE93 (Peterson et al. [1998] in the central North Atlantic Ocean and Buhr et al. [1996] in the western North Atlantic Ocean); 8, Izaña [Fischer et al., 1998]; 9, Tropospheric Ozone Production about the Spring Equinox [Wang et al., 2003]. Observations from Emmons et al. [1997] are average \pm standard deviation of several field campaigns over the western Atlantic Ocean; observations at MLO and Izaña are for downslope conditions, and observations at JFJ are for undisturbed conditions. Observations from Peterson et al. [1998] are average \pm standard deviation of two periods in the FT.

${ }^{\mathrm{d}} \mathrm{NO}_{y}$ at the Pico Mountain station determined in dry conditions.

of-cloud periods can be used to estimate the mixing ratio of cloud-scavenged $\mathrm{NO}_{y}$ species, i.e., $\mathrm{HNO}_{3}$, by assuming that $\mathrm{HNO}_{3}$ is scavenged into clouds droplets during in-cloud periods [Peterson et al., 1998]. (Even for the smallest observed orographic clouds $(\sim 1500 \mathrm{~m}$ radius $)$ and typical higher wind speeds $\left(\sim 12 \mathrm{~m} \mathrm{~s}^{-1}\right.$; 95th percentile of wind speed observations when $\mathrm{NO}_{y}$ was available), there was enough time $(\sim 125 \mathrm{~s})$ for $\mathrm{HNO}_{3}$ to be scavenged into the cloud droplets before air reached the measurement site.) For this purpose, we subdivided the observations into periods above $96 \%$ RH and below $60 \%$ RH in order to identify incloud and out-of-cloud intervals at the site, respectively. The RH cutoffs were selected so that both subsets contained similar numbers of data points and, at the same time, cloud and cloud-free periods were present at the measurement site.
Archived photos of the conditions at the station confirmed cloud and cloud-free periods under those cutoffs. Monthly $\mathrm{HNO}_{3}{ }^{*}$ values were determined by subtracting the monthly averages of $\mathrm{NO}_{y}$ observed during "in-cloud" periods from those observed during "out-of-cloud" periods; PAN* was determined by subtracting $\mathrm{NO}_{x}$ from $\mathrm{NO}_{y}$ in simultaneous observations during in-cloud periods, and $\mathrm{NO}_{x}$ and $\mathrm{NO}_{y}$ mixing ratios were determined using direct observations made during out-of-cloud periods. (The terms $\mathrm{HNO}_{3}{ }^{*}$ and PAN* are used here to indicate estimated, not directly measured values of these species.) Table 3 summarizes the $\mathrm{NO}_{y}$ and $\mathrm{NO}_{x}$ levels during in-cloud and out-of-cloud periods, and the derived fraction of reactive nitrogen species on a seasonal basis, i.e., $\left[\mathrm{HNO}_{3}{ }^{*}\right] /\left[\mathrm{NO}_{y}\right]$, $\left[\mathrm{PAN}{ }^{*}\right] /$ $\left[\mathrm{NO}_{y}\right]$, and $\left[\mathrm{NO}_{x}\right] /\left[\mathrm{NO}_{y}\right]$. Figure $4 \mathrm{a}$ shows the monthly

Table 3. Partitioning of $\mathrm{NO}_{y}$ at the Pico Mountain Station

\begin{tabular}{|c|c|c|c|c|c|c|c|c|c|}
\hline \multirow[b]{2}{*}{ Season } & \multicolumn{2}{|c|}{ Out-of-Cloud $^{\mathrm{a}}$} & \multicolumn{2}{|c|}{ In-Cloud ${ }^{\mathrm{b}}$} & \multirow[b]{2}{*}{$\mathrm{PAN}^{* \mathrm{c}}$} & \multirow[b]{2}{*}{$\mathrm{HNO}_{3}{ }^{* \mathrm{c}}$} & \multirow[b]{2}{*}[\mathrm{HNO}_{3}{}^{*}]{$/\left[\mathrm{NO}_{y}\right]^{\mathrm{d}}$} & \multirow[b]{2}{*}[\mathrm{PAN}^{*}]{$/\left[\mathrm{NO}_{y}\right]^{\mathrm{d}}$} & \multirow[b]{2}{*}[\mathrm{NO}_{x}]{$/\left[\mathrm{NO}_{y}\right]^{\mathrm{e}}$} \\
\hline & $\mathrm{NO}_{y}{ }^{\mathrm{c}}$ & $\mathrm{NO}_{x}^{\mathrm{c}}$ & $\mathrm{NO}_{y}{ }^{\mathrm{c}}$ & $\mathrm{NO}_{x}^{\mathrm{c}}$ & & & & & \\
\hline Spring & $259 \pm 120(451)$ & $23 \pm 11(229)$ & $132 \pm 101(351)$ & $21 \pm 12(115)$ & $117 \pm 81(114)$ & $127 \pm 31$ & $0.49 \pm 0.25$ & $0.45 \pm 0.12$ & $0.11 \pm 0.05$ \\
\hline Summer & $365 \pm 162(858)$ & $37 \pm 18(608)$ & $105 \pm 110(478)$ & $27 \pm 13(333)$ & $76 \pm 129(301)$ & $260 \pm 30$ & $0.71 \pm 0.17$ & $0.21 \pm 0.08$ & $0.12 \pm 0.08$ \\
\hline & $223 \pm 118(751)$ & $38 \pm 20(508)$ & $117 \pm 67(981)$ & $29 \pm 18(530)$ & $66 \pm 42(434)$ & $106 \pm 19$ & $0.47 \pm 0.18$ & $0.30 \pm 0.04$ & $0.19 \pm 0.07$ \\
\hline Winter & $157 \pm 74(559)$ & $28 \pm 13(487)$ & $115 \pm 70(500)$ & $20 \pm 12(307)$ & $63 \pm 36(279)$ & $42 \pm 18$ & $0.27 \pm 0.23$ & $0.40 \pm 0.06$ & $0.19 \pm 0.06$ \\
\hline
\end{tabular}



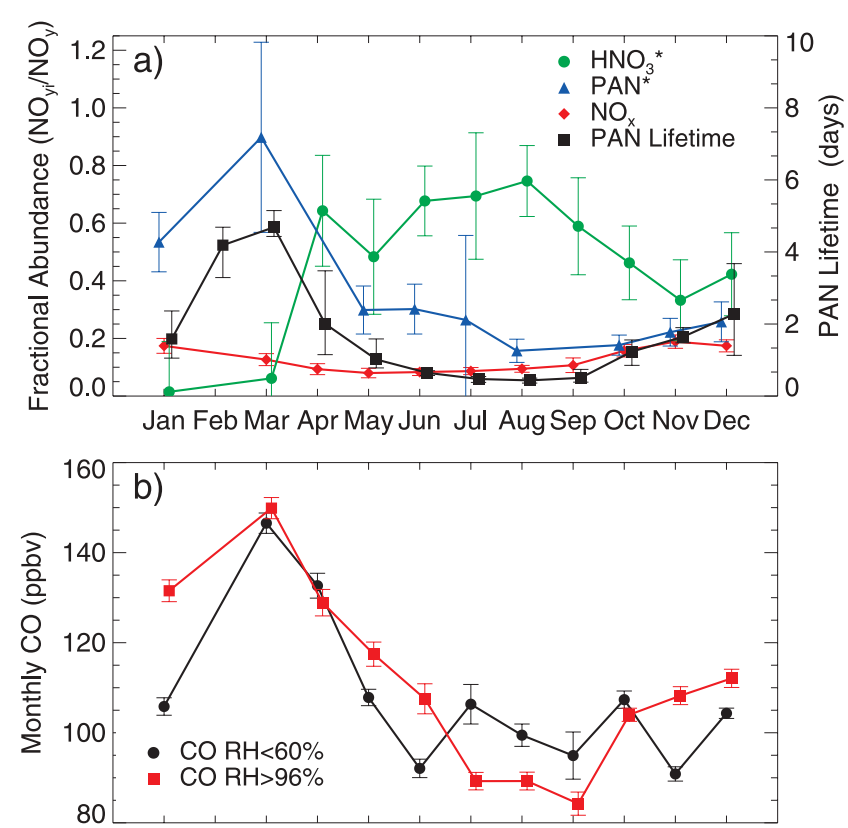

Jan Feb Mar Apr May Jun Jul Aug Sep Oct Nov Dec

Figure 4. Seasonal cycle of (a) partitioning of reactive nitrogen $\left(\mathrm{HNO}_{3}{ }^{*}, \mathrm{PAN}^{*}\right.$, and $\left.\mathrm{NO}_{x}\right)$ and average lifetime of PAN with respect to thermal decomposition in the air arriving at the Pico Mountain station and (b) $\mathrm{CO}$ in in-cloud $(\mathrm{RH}>96 \%)$ and out-of-cloud $(\mathrm{RH}<60 \%)$ periods. (See text for explanation.) Symbols represent monthly averages for $\mathrm{HNO}_{3}{ }^{*}$ (green circles), $\mathrm{PAN}^{*}$ (blue triangles), $\mathrm{NO}_{x}$ (red diamonds), $\mathrm{CO} \mathrm{RH}>96 \%$ (red squares) and $\mathrm{CO} \mathrm{RH}<60 \%$ (black circles), and average of the monthly means for PAN lifetime (black squares). Vertical bars indicate the 2 standard error of the mean for $\mathrm{CO}, \mathrm{NO}_{x}$, and PAN*; the uncertainty $(2 \sigma)$ based on propagation of errors for $\mathrm{HNO}_{3}{ }^{*}$; and the minimum and maximum estimated monthly PAN lifetime.

variation of the $\left[\mathrm{HNO}_{3}{ }^{*}\right] /\left[\mathrm{NO}_{y}\right],\left[\mathrm{PAN}^{*}\right] /\left[\mathrm{NO}_{y}\right]$, and $\left[\mathrm{NO}_{x}\right] /$ $\left[\mathrm{NO}_{y}\right]$.

[43] A limited number of more direct estimates of $\mathrm{HNO}_{3}{ }^{*}$ were also made, using alternating measurements of $\left(\mathrm{NO}_{y}-\mathrm{HNO}_{3}\right)$ and $\mathrm{NO}_{y}$. Measurements of $\left(\mathrm{NO}_{y}-\mathrm{HNO}_{3}\right)$ were made in August 2004 and 2005 by removing $\mathrm{HNO}_{3}$ from $\mathrm{NO}_{y}$ before sampling using a nylon filter attached to the $\mathrm{NO}_{y}$ inlet [e.g., Parrish et al., 1986; Yamamoto et al., 2001]. $\mathrm{HNO}_{3}$ was determined by difference from $\mathrm{NO}_{y}$; PAN* was determined as $\left(\mathrm{NO}_{y}-\mathrm{HNO}_{3}\right)$ minus $\mathrm{NO}_{x}$. These measurements provide an additional method to test the consistency of our approach. The fraction of reactive nitrogen species estimated directly from these tests $\left(53-62 \% \mathrm{HNO}_{3}\right.$, $23-34 \%$ PAN* and $9-16 \% \mathrm{NO}_{x}$ ) is similar to that deduced for the summer $\left(71 \pm 9 \% \mathrm{HNO}_{3}{ }^{*}, 21 \pm 8 \% \mathrm{PAN}^{*}\right.$ and $12 \pm$ $8 \% \mathrm{NO}_{x}$ ).

[44] To confirm that the changes in RH used in this analysis were independent of the origin and the chemical history on the air masses, we inspected the variation of $\mathrm{CO}$ in the in-cloud and out-of-cloud periods when $\mathrm{NO}_{y}$ measurements were available. As shown in Figure 4b, CO did not exhibit a clear relationship with RH, i.e., monthly $\mathrm{CO}$ averages were variable all year-round, independent of in-cloud and out-of-cloud conditions. However, significant larger monthly $\mathrm{CO}$ means for the out-of-cloud periods from July to September may indicate a dominance of fireimpacted boreal region outflow, which is characterized by low RH and elevated CO levels [Val Martin et al., 2006]. This influence of boreal emissions during out-of-cloud conditions may have resulted in an overestimation of $\mathrm{HNO}_{3}$ and underestimation of PAN levels during summer, since $\mathrm{NO}_{y}$ is enhanced during boreal wildfire events. Conversely, significant smaller monthly CO means for the out-of-cloud periods from November to January may have resulted in an overestimation of $\mathrm{HNO}_{3}$ and underestimation of PAN levels.

[45] In this analysis, we neglected the possible influence of aerosol and alkyl nitrates. The $\mathrm{NO}_{x, y}$ system inlet used at the Pico Mountain station excludes large aerosol particles, but allowed sampling of the $\$ 10$ micron aerosol fraction [Hangal and Willeke, 1990; Peterson and Honrath, 1999]. However, submicron size aerosol nitrates are not efficiently measured in our system as conversion efficiency for these compounds are low [Miyazaki et al., 2005]. The contribution of alkyl nitrates to $\mathrm{NO}_{y}$ in the remote marine troposphere is very small [Singh et al., 2007; Reeves et al., 2007]. For example, alkyl nitrates accounted for less than $2 \%$ of the tropospheric $\mathrm{NO}_{y}$ in the lower FT over the North Atlantic Ocean during the International Consortium for Atmospheric Research on Transport and Transformation (ICARTT) study [Singh et al., 2007]. Thus, although the presence of alkyl nitrates may introduce a bias in our estimation of PAN, this bias is expected to be very small.

\subsubsection{Variation of $\mathrm{NO}_{y}$ Partitioning}

[46] From Figure 4a, it is evident that although reactive nitrogen is principally emitted as NO, it largely exists in its secondary reservoir forms in the central North Atlantic lower FT all year-round. Low $\mathrm{NO}_{x} / \mathrm{NO}_{y}$ ratios $(11-19 \%$; Table 3) are consistent with long-range transport and photochemical processing times to the measurement site. Because of the relatively short lifetime of $\mathrm{NO}_{x}$ compared to $\mathrm{NO}_{y}, \mathrm{NO}_{x} / \mathrm{NO}_{y}$ is expected to decrease with increasing air mass age. In the remote lower FT, typical $\mathrm{NO}_{x} / \mathrm{NO}_{y}$ values of $10-17 \%$ have been observed all year-round [Ridley et al., 1998; Atlas et al., 1992; Singh et al., 2007], consistent with the values observed at the Pico Mountain station.

[47] The shift from dominance of PAN in winter-spring to dominance of $\mathrm{HNO}_{3}$ in summer-fall in Figure 4a is noteworthy. The small contribution of PAN during the summer (21 $\pm 8 \%$; Table 3) is attributed to the strong thermal decomposition of PAN to $\mathrm{NO}_{x}$ in the North Atlantic lower FT. Conversely, the large fraction of $\mathrm{HNO}_{3}(71 \pm 9 \%$; Table 3 ) is directly related to the efficient formation of $\mathrm{HNO}_{3}$ from reaction of $\mathrm{NO}_{x}$ with $\mathrm{OH}$, as conversion of $\mathrm{NO}_{x}$ to $\mathrm{HNO}_{3}$ is 5 times faster during summer than winter [Logan, 1983]. Indirectly, the strong decomposition of PAN during the summer may result in the formation of $\mathrm{HNO}_{3}$ as $\mathrm{NO}_{x}$ is ultimately converted to $\mathrm{HNO}_{3}$.

[48] To evaluate the effect of temperature on PAN, we examined the lifetime of PAN with respect to thermal decomposition in the air masses during transit to the Pico Mountain station. For this purpose, we extracted the average temperature from the HYSPLIT model output [Draxler and Rolph, 2003] for the 10-day backward trajectories arriving at the measurement site. More information on the HYSPLIT backward trajectories is presented elsewhere [Honrath et 
Table 4. Partitioning of $\mathrm{NO}_{y}$ Estimates Reported From ICARTT, NARE, and Pico Mountain Studies ${ }^{\mathrm{a}}$

\begin{tabular}{|c|c|c|c|c|c|c|}
\hline Study & Altitude $(\mathrm{km})$ & Season & {$\left[\mathrm{NO}_{x}\right] /\left[\mathrm{NO}_{y}\right]^{\mathrm{b}}$} & {$[\mathrm{PAN}] /\left[\mathrm{NO}_{y}\right]^{\mathrm{a}}$} & {$\left[\mathrm{HNO}_{3}\right] /\left[\mathrm{NO}_{y}\right]^{\mathrm{b}}$} & Source $^{\mathrm{c}}$ \\
\hline Pico Mountain & 2.2 & Spring & 11 & 45 & 49 & 1 \\
\hline Pico Mountain & 2.2 & Summer & $9-16$ & $21-34$ & $53-71$ & \\
\hline Pico Mountain & 2.2 & Fall & 19 & 29 & 47 & \\
\hline Pico Mountain & 2.2 & Winter & 19 & 40 & 27 & \\
\hline NARE96 & $2-8$ & Spring & 11 & 42 & 47 & 2 \\
\hline NARE96 & $2-8$ & Spring & 5 & 35 & 60 & 3 \\
\hline NARE96 & $2-4^{\mathrm{d}}$ & Spring & 5 & & & 3 \\
\hline NARE96 & $4-6^{d}$ & Spring & 3 & & & 3 \\
\hline NARE97 & $2-8$ & Fall & 8 & 34 & 57 & 4 \\
\hline NARE97 & $2-8$ & Fall & 6 & 33 & 61 & 3 \\
\hline NARE97 & $2-4$ & Fall & 7 & 21 & 72 & 3 \\
\hline NARE97 & $4-6$ & Fall & 6 & 40 & 54 & 3 \\
\hline ICARTT & $2.5-6.5$ & Summer & 13 & 47 & 40 & 5 \\
\hline ICARTT & $2.5-3.5$ & Summer & - & - & 54 & \\
\hline ICARTT & $3.5-6.5$ & Summer & 14 & 53 & 33 & \\
\hline ICARTT & $2-8$ & Summer & 8 & 35 & 44 & 6 \\
\hline ICARTT & $2-4$ & Summer & 8 & 26 & 60 & \\
\hline ICARTT & $4-6$ & Summer & 7 & 43 & 43 & \\
\hline
\end{tabular}

${ }^{\mathrm{a}} \mathrm{NO}_{y}$ estimates given in percent. Dashes indicate that values are not reported.

${ }^{\mathrm{b}} \mathrm{NO}_{y}$ composition reported is as follows: for Pico Mountain, in spring, fall, and winter average percentages (Table 3 ) and in summer minimum and maximum average percentages reported in Table 3 and estimated from alternating measurements of $\left(\mathrm{NO}_{y}-\mathrm{HNO}_{3}\right)$ and $\mathrm{NO}_{y}$ (see text for explanation) and for NARE and ICARTT, average percentages reported in North American outflow [Parrish et al., 2004; Li et al., 2004; Hudman et al., 2007], percentages calculated using means reported every 2-km altitude bins [Singh et al., 2007], or average percentages calculated using $10-\mathrm{s}$ average observations east of $60^{\circ} \mathrm{W}$ (D. Parrish, NOAA, United States, personal communication, 2007).

'Sources are as follows: 1, This work; 2, Parrish et al. [2004]; 3, D. Parrish (NOAA, United States, personal communication, 2007); 4, Parrish et al. [2004] and Li et al. [2004]; 5, Hudman et al. [2007]; 6, Singh et al. [2007].

${ }^{\mathrm{d} A v e r a g e s}$ with fewer than 25 data points are not shown.

al., 2004; Val Martin et al., 2006]. We calculated the average temperature in the air masses from the measurement site to 3 days upwind. This average temperature is the typical temperature that the air masses encounter before arriving at the Pico Mountain station. We then used those average values to calculate the lifetime of PAN. Figure 4a shows the lifetime of PAN in the air masses determined from the monthly average upwind temperatures from July 2002 to August 2005. The average lifetime of PAN under those conditions ranged from 5 days in March (average temperature $-4.4^{\circ} \mathrm{C}$ ) to 0.5 days in August (average temperature $8.9^{\circ} \mathrm{C}$ ). Therefore, the dominance of PAN in $\mathrm{NO}_{y}$ in winter-early spring is consistent with the longer lifetime of PAN in the air masses, whereas the rapid decomposition of PAN in the air masses during the summer results in the lower PAN fraction observed during that season. Because of the rapid oxidation of $\mathrm{NO}_{x}$ by $\mathrm{OH}$ in the summer ( $\leqslant 1$ day), PAN decomposition may result in the formation of $\mathrm{HNO}_{3}$ before the air masses reach the Pico Mountain station.

\subsubsection{Comparison to Previous Observations}

[49] A comparison of the distribution of $\mathrm{NO}_{y}$ species at the Pico Mountain station to those collected over the western North Atlantic Ocean during the North Atlantic Regional Experiment (NARE) and ICARTT aircraft campaigns from spring to fall [Parrish et al., 2004; Li et al., 2004; Singh et al., 2007; Hudman et al., 2007] allows for some speculation on the behavior of nitrogen oxides across the North Atlantic region. Table 4 compares the fractions of reactive nitrogen species measured during the ICARTT and NARE campaigns with those estimated at the Pico Mountain station.

[50] Our spring-fall estimates of the fraction of $\mathrm{NO}_{x}$ (9-19\%), PAN* $(21-45 \%)$ and $\mathrm{HNO}_{3}^{*}(47-71 \%)$ are similar to those observed over the western Atlantic Ocean in those other studies $\left(5-13 \%\right.$ for $\mathrm{NO}_{x}, 21-47 \%$ for PAN and $40-72 \%$ for $\mathrm{HNO}_{3}$; range of averages in $2-4 \mathrm{~km}$ and $2.5-6.5 \mathrm{~km}$ altitudes from Table 4). However, as discussed in section 3.2.1, levels of $\mathrm{NO}_{y}$ at the Pico Mountain station are 2-3 times lower than those over the western Atlantic region, indicating the significant removal of $\mathrm{HNO}_{3}$ during transport to the measurement site. These results suggest that to maintain the observed fractions of $\mathrm{NO}_{x}$ and $\mathrm{HNO}_{3}{ }^{*}$ at the Pico Mountain station, decomposition of PAN to $\mathrm{NO}_{x}$ and further oxidation of $\mathrm{NO}_{x}$ to $\mathrm{HNO}_{3}$ must occur in the air masses.

\subsubsection{Comparison to GEOS-Chem}

[51] Global chemical transport models have important difficulties in simulating nitrogen oxides [e.g., Emmons et al., 1997; Thakur et al., 1999; Singh et al., 2007]. As a first evaluation of a CTM in the lower FT over the central North Atlantic region using the Pico Mountain measurements, we compare the Pico mountain observations to simulations from the well-known CTM GEOS-Chem. Figures $5 \mathrm{a}-5 \mathrm{c}$ compares the measurements with results obtained from GEOS-Chem for $\mathrm{NO}_{y}, \mathrm{HNO}_{3}{ }^{*}, \mathrm{PAN}^{*}$ and $\mathrm{NO}_{x}$. Additionally, the model-data comparison for $\mathrm{CO}$ is shown in Figure 5d. GEOS-Chem simulations were available from January to December 2005, whereas data from the Pico Mountain station in 2005 were available only from January to August. To be able to compare a full year cycle, we compared GEOS-Chem simulations to all data in 2002 2005. To avoid potential biases resulting from interannual variability, we also compared GEOS-Chem simulations to the data available in 2005 only. The model-data comparison focuses mainly on the median since this value is less affected by the variability resulting from large episodic events, with the exception of $\mathrm{HNO}_{3}{ }^{*}$ and $\mathrm{PAN}^{*}$, which are based on the estimated averages. Vertical bars reflect the 

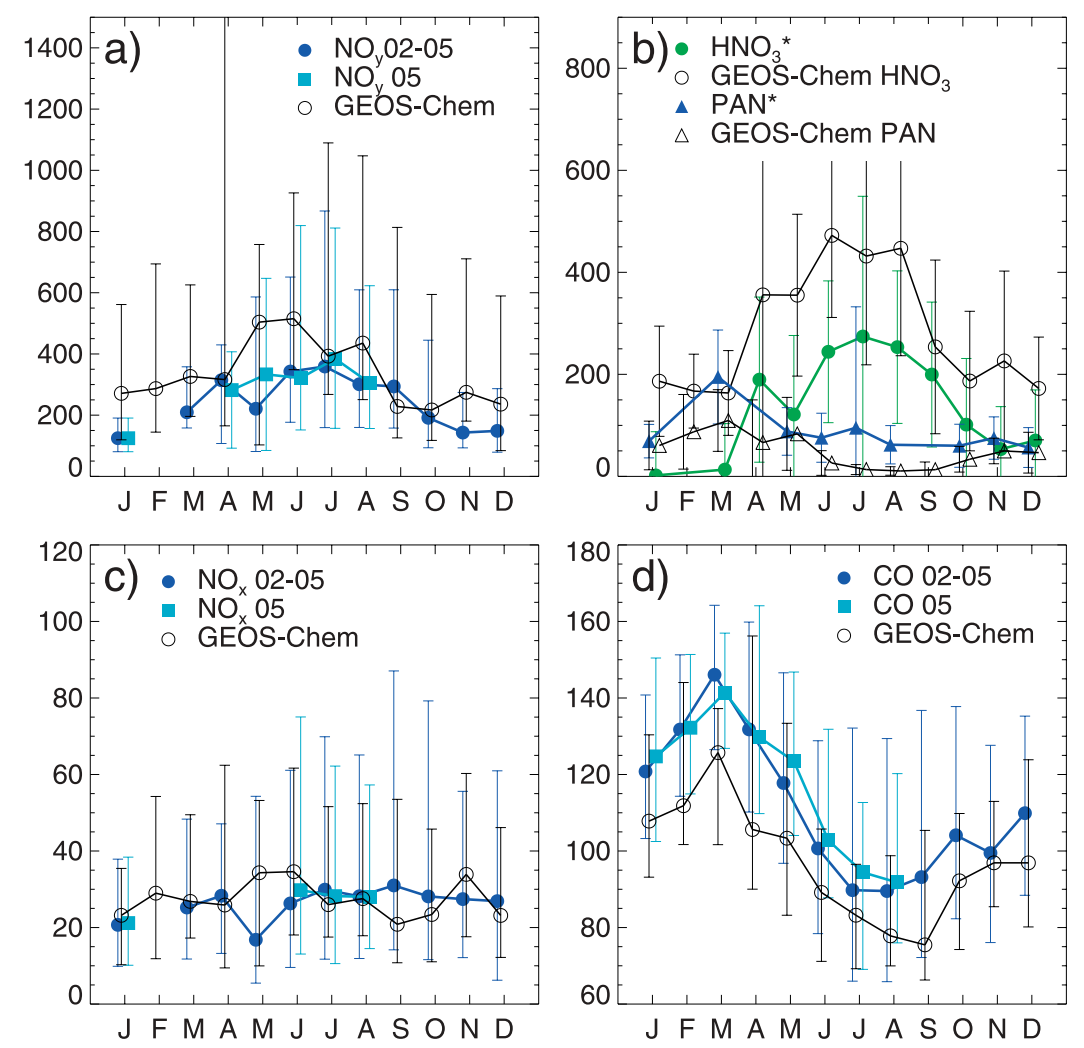

Figure 5. Comparison of observations (a) $\mathrm{NO}_{y}$ in dry conditions (see section 3.3.1 for explanation), (b) $\mathrm{HNO}_{3} *$ and PAN*, (c) $\mathrm{NO}_{x}$, and (d) $\mathrm{CO}$ to GEOS-Chem simulations. Symbols represent monthly medians in 2002-2005 (blue circles) and in 2005 (cyan squares) for $\mathrm{NO}_{y}, \mathrm{NO}_{x}$, and $\mathrm{CO}$; monthly medians in 2005 for GEOS-Chem $\mathrm{NO}_{y}, \mathrm{NO}_{x}$, and $\mathrm{CO}$ (blue squares); monthly averages in 2002-2005 for $\mathrm{HNO}_{3} *$ (green circles) and PAN* (blue triangles) and in 2005 for GEOS-Chem $\mathrm{HNO}_{3}$ (open circles) and GEOS-Chem PAN (open triangles). Vertical bars indicate the 10th and 90th percentile for observed and simulated $\mathrm{NO}_{y}, \mathrm{NO}_{x}$, and $\mathrm{CO}$; the standard deviation of all estimates of PAN* and GEOS-Chem simulations of $\mathrm{HNO}_{3}$ and PAN; and the standard deviation based on propagation of errors for $\mathrm{HNO}_{3}$ *

population variability, and not the uncertainty in the medians and means, which are much less since at least 100 points were used in the calculation of each median and mean.

[52] From Figure 5a, it is apparent that GEOS-Chem reproduces the annual variation of $\mathrm{NO}_{y}$ observed at the Pico Mountain station. However, GEOS-Chem tends to overestimate $\mathrm{NO}_{y}$. As shown in Figure $5 \mathrm{~b}$, this overestimation is mainly because of an excess of $\mathrm{HNO}_{3}$. For example, during summer, GEOS-Chem produces monthly $\mathrm{HNO}_{3}$ medians 50-150 pptv greater than the $2005 \mathrm{NO}_{y}$ medians at the Pico Mountain station, and about a factor of two higher than our estimated $\mathrm{HNO}_{3}$. This problem is known to occur in multiple CTMs [e.g., Lawrence and Crutzen, 1998; Bey et al., 2001; Singh et al., 2007], and may be related to an overestimation of $\mathrm{OH}$ concentrations [Singh et al., 2007], to insufficient scavenging in the model [Bey et al., 2001] or a combination of these and other causes.

[53] Because of the scavenging scheme used in GEOS-Chem, it has been suggested that the model allows for significant escape of nitrogen oxides to the lower FT and reasonably accurate simulation of shallow convection from the United States BL to the lower FT during summer [Li et al., 2004; Hudman et al., 2007]. The strong summer peak in the GEOS-Chem $\mathrm{NO}_{y}$ cycle indicates that enhanced summertime export may be partially responsible for the increased summertime $\mathrm{NO}_{y}$ levels over the central North Atlantic lower FT, as suggested above. However, the larger summertime values produced by GEOS-Chem indicate an inability to capture the actual magnitude of $\mathrm{NO}_{y}$ over the North Atlantic lower FT.

[54] Figure 5b shows the comparison between simulated PAN levels and observations. The model produces an annual variation of PAN similar to that estimated at the Pico Mountain station. However, GEOS-Chem tends to underestimate PAN, in particular from July to September, when GEOS-Chem values are a factor of 6-7 times lower than the observations. This behavior may be related to an excessive decomposition of PAN in the model resulting from inaccurate temperature parameters and/or location of the air masses, or underestimation of $\mathrm{NO}_{x}$ and/or $\mathrm{NMHC}$ emissions. Finally, a removal efficiency for $\mathrm{HNO}_{3}$ less than $100 \%$ within the clouds present at the Pico Mountain station could also contribute to this model-data difference, since PAN* was calculated by assuming complete removal of $\mathrm{HNO}_{3}$ in the presence of clouds at the station. Were this the case, it would also reduce the $\mathrm{HNO}_{3}$ model-data difference during summer, but only by $20 \%$, not changing the conclusion that $\mathrm{HNO}_{3}$ exceeds the simulated values. 
[55] A comparison of simulated and observed $\mathrm{NO}_{x}$ levels is shown in Figure 5c. Similar to our measurements, GEOS-Chem does not simulate a clear seasonal cycle for the median $\mathrm{NO}_{x}$ values. GEOS-Chem simulations produce monthly medians (21-35 pptv) similar to those observed at the Pico Mountain station (21-30 pptv in 2005 and 1629 pptv in 2002-2005). However, the model does not capture the very large variability in the $\mathrm{NO}_{x}$ mixing ratios, particularly that associated with transport of boreal wildfires in summer 2005. This is not unexpected, since the version of GEOS-Chem used here did not incorporate interannual variation in boreal fire activity.

[56] Figure 5d shows observed and modeled $\mathrm{CO}$ values. GEOS-Chem CO exhibits a seasonal variation similar to that observed at the Pico Mountain station, but systematically underestimates the $\mathrm{CO}$ observations in 2005 by 10 to $25 \mathrm{ppbv}$. This behavior has been noted previously [Bey et $a l ., 2001]$, and may be related to an excess of $\mathrm{OH}$ in the model and/or to the underestimation of the $\mathrm{CO}$ emissions. During July-September, this difference is more apparent. GEOS-Chem simulates a sharp decrease of $\mathrm{CO}$ through these months, whereas the observed $\mathrm{CO}$ remain stable. This may be related to the strong impact of boreal wildfire emissions during these months in both 2004 and 2005, which it is not simulated by the fire emission inventory used in this GEOS-Chem simulation.

[57] This comparison shows that, although current chemical transport models have become more sophisticated [Singh et al., 2007], uncertainties in simulating nitrogen oxides in the remote lower FT remain. These uncertainties are clearly related to errors in emission sources and limitations in our understanding of the nitrogen oxides chemistry in the remote troposphere.

\section{Summary and Conclusions}

[58] Measurements of nitrogen oxides made at the Pico Mountain station from July 2002 to August 2005 were used to estimate the magnitude and seasonal variability of nitrogen oxides over the central North Atlantic lower FT and to determine the processes that contribute to this variability.

[59] These measurements reveal the presence of a welldefined seasonal cycle in the variability of nitrogen oxides in the background central North Atlantic lower FT, with larger mixing ratios during the summertime. We attribute the presence of larger summertime nitrogen oxides levels to impacts of boreal wildfire emissions and a more efficient export of $\mathrm{NO}_{y}$ from eastern North America during this season. Median $\mathrm{NO}_{x}(17-31 \mathrm{pptv})$ and $\mathrm{NO}_{y}(125-338 \mathrm{pptv})$ observed at the Pico Mountain station were lower than those previously observed over the western North Atlantic region and similar to those observed at the remote marine North Pacific MLO station. The observed $\mathrm{NO}_{x}$ and $\mathrm{NO}_{y}$ levels were consistent with long-range transport of emissions with significant removal upwind of the measurement site.

[60] Observations of $\mathrm{NO}_{x}$ and $\mathrm{NO}_{y}$ and estimates of PAN and $\mathrm{HNO}_{3}$ indicate that reactive nitrogen over the central North Atlantic lower FT largely exists in the form of $\mathrm{HNO}_{3}$ and PAN, independent of the season. The shift from dominance of PAN in winter-spring to dominance of $\mathrm{HNO}_{3}$ in summer-fall is attributed to strong decomposition of PAN to $\mathrm{NO}_{x}$ and efficient formation of $\mathrm{HNO}_{3}$ from rapid reaction of $\mathrm{NO}_{x}$ with $\mathrm{OH}$ during the summer and fall seasons.

[61] Estimated $\mathrm{HNO}_{3}$ accounts for 53-71\% of $\mathrm{NO}_{y}$ during the summer. Given the significant removal of $\mathrm{NO}_{y}$ during transport, this suggests that the oxidation of $\mathrm{NO}_{x}$ resulting from decomposition of $\mathrm{PAN}$ in the air masses during subsidence, or advection over the ocean with minimal removal, results in a significant source of $\mathrm{HNO}_{3}$ to the central North Atlantic lower FT. The decomposition of PAN in the air masses has important implications for $\mathrm{O}_{3}$ formation, since released $\mathrm{NO}_{x}$ is available to form $\mathrm{O}_{3}$ before oxidation to $\mathrm{HNO}_{3}$ during transport to the central North Atlantic lower FT.

[62] A comparison of nitrogen oxides observations with GEOS-Chem simulations indicates that GEOS-Chem reproduces some of the seasonal variation of nitrogen oxides over the central North Atlantic lower FT. However, it does not capture the magnitude of the cycles. Important differences were found for PAN (a critical species in the global formation of $\mathrm{O}_{3}$ via dispersal and release of $\mathrm{NO}_{x}$ ) and $\mathrm{HNO}_{3}$. This underscores the need for continuing evaluation of the accuracy of simulations of nitrogen oxides chemistry in highly aged pollution plumes.

[63] Acknowledgments. We thank many people involved in the development, installation, and maintenance of the Pico Mountain station and the $\mathrm{NO}_{x, y}$ system, in particular, M. Dziobak (Michigan Tech, United States), P. Fialho (Azores University, Portugal), D. Helmig (Colorado University, United States), and D. Tanner (Colorado University, United States). In addition, we thank J. Kleissl (University of California at San Diego, United States) for providing the analysis of upslope flow periods, D. Parrish (NOAA, United States) for supplying the NARE96 and NARE97 data set, B. Ridley (National Center for Atmospheric Research (NCAR), United States) for providing the MLOPEX data set, D. Henriques (Institute of Meteorology, Portugal) for providing the ECMWF data used to run the FLEXPART simulations, and the NOAA Air Resources Laboratory for provision of the HYSPLIT transport model. This work was supported by NOAA, Office of Global Programs grants NA16GP1658, NA86GP0325, and NA03OAR4310002; the National Science Foundation grants ATM0215843, ATM-0535486, and INT-0110397; Azores Cooperative Initiative Program USDA grant 58-3625-5-127; Azores Regional Secretariat for Science and Technology (project M1.2.1/I/006/2005, project M1.2.1/I/ 001/2008, and project M1.2.1/I/002/2008); and Program INTER-REG IIIB, Azores, Madeira, and Canarias (project CLIMARCOST FEDERINTERREG IIIB-05/MAC/2.3/A1). Q.B. Li's research is performed at the Jet Propulsion Laboratory, California Institute of Technology, under contract with NASA and was supported in part by NASA's Atmospheric Composition Program under P. DeCola.

\section{References}

Andreae, M., and P. Merlet (2001), Emissions from trace gases and aerosols from biomass burning, Global Biogeochem. Cycles, 15, 955-966.

Atlas, E. L., B. A. Ridley, G. Hubler, J. G. Walega, M. A. Carroll, D. D. Montzka, B. J. Huebert, R. B. Norton, F. E. Grahek, and S. Schauffler (1992), Partitioning and budget of $\mathrm{NO}_{y}$ species during the Mauna Loa Observatory Photochemistry Experiment, J. Geophys. Res., 97, $10,449-10,462$.

Bey, I., et al. (2001), Global modeling of tropospheric chemistry with assimilated meteorology: Model description and evaluation, J. Geophys. Res., 106, 23,073-23,096.

Bollinger, M. J., R. E. Sievers, D. W. Fahey, and F. C. Fehsenfeld (1983), Conversion of nitrogen dioxide, nitric acid, and $n$-propyl nitrate to nitric oxide by gold-catalyzed reduction with carbon monoxide, Anal. Chem., $55,1980-1986$

Bradshaw, J., D. Davis, G. Grodzinsky, R. Newell, S. Sandholm, and S. Liu (2000), Observed distributions of nitrogen oxides in the remote free troposphere from NASA Global Tropospheric Experiment programs, Rev. Geophys., 38, 61-116.

Buhr, M. P., K. J. Hsu, C. M. Liu, R. Liu, L. Wei, Y. C. Liu, and Y. S. Kuo (1996), Trace gas measurements and air mass clasification from a ground station in Taiwan during the PEM-West A experiment (1991), J. Geophys. Res., 101, 2025-2035. 
Chameides, W. L. (1984), The photochemistry of a remote marine stratiform cloud, J. Geophys. Res., 89, 4739-4755.

Chandra, S., J. R. Ziemke, X. Tie, and G. Brasseur (2004), Elevated ozone in the troposphere over the Atlantic and Pacific oceans in the Northern Hemisphere, Geophys. Res. Lett., 31, L23102, doi:10.1029/ 2004GL020821

Crutzen, P. J. (1979), The role of $\mathrm{NO}$ and $\mathrm{NO}_{2}$, Ann. Revu. Earth Planet. Sci., 7, 443-472.

Derwent, R., D. Stevenson, W. Collins, and C. Johnson (2004), Intercontinental transport and the origins of the ozone observed at surface sites in Europe, Atmos. Environ., 38, 1891-1901.

DiNunno, B., et al. (2003), Central/eastern North Pacific photochemical precursors distributions for fall/spring seasons as defined by airborne field studies, J. Geophys. Res., 108(D2), 8240, doi:10.1029/2001JD001044.

Draxler, R., and G. Rolph (2003), HYSPLIT4 Model, http://www.arl.noaa. gov/ready/hysplit4.html, NOAA Air Resour. Lab., Silver Spring, Md.

Duncan, B., R. Martin, A. Staudt, R. Yevich, and J. Logan (2003), Interannual and seasonal variability of biomass burning emissions constrained by satellite observations, J. Geophys. Res., 108(D2), 4100, doi:10.1029/ 2002JD002378.

Edwards, D. P., et al. (2004), Observations of carbon monoxide and aerosols from the Terra satellite: Northern Hemisphere variability, J. Geophys. Res., 109, D24202, doi:10.1029/2004JD004727.

Emmons, L., et al. (1997), Climatologies of $\mathrm{NO}_{x}$ and $\mathrm{NO}_{y}$ : A comparison of data and models, Atmos. Environ., 31, 1851-1904.

Emmons, L. K., D. A. Hauglustaine, J.-J. Müller, M. A. Carroll, G. P. Brasseur, D. Brunner, J. Staehelin, V. Thouret, and A. Marenco (2000), Data composites of airborne observations of tropospheric ozone and its precursors, J. Geophys. Res., 105, 20,497-20,538.

Environmental Protection Agency (1997), National air pollutant emission trends, 1990-1997, Tech. Rep. EPA 454/R-97-011, Washington, D. C.

Environmental Protection Agency (2006), Air quality criteria for ozone and related photochemical oxidants, Tech. Rep. EPA 600/R-05/004aF-cF, Washington, D. C

European Center for Medium-Range Weather Forecasts (2005), Users guide to ECMWF products 4.0, Tech. Rep. Meteorol. Bull. M3.2, Reading, U. K

European Monitoring and Evaluation Program (1997), Transboundary air pollution in Europe, part I, Emissions, dispersion and trends of acidifying and eutrophying agents, Tech. Rep. EMEP/MSC-W Rep. 1/97, Norw Meteorol. Inst., Oslo.

Fahey, D. W., C. S. Eubank, G. Hubler, and F. C. Fehsenfeld (1985), Evaluation of a catalytic reduction technique for the measurement of total reactive odd-nitrogen $\mathrm{NO}_{y}$ in the atmosphere, J. Atmos. Chem., 3 , $435-468$.

Fischer, H., et al. (1998), Trace gas measurements during the Oxidizing Capacity of the Tropospheric Atmosphere campaign 1993 at Izaña, J. Geophys. Res., 103, 13,505-13,518.

Garrett, T. J., L. Avey, P. I. Palmer, A. Stohl, J. A. Neuman, C. A. Brock, T. B. Ryerson, and J. S. Holloway (2006), Quantifying wet scavenging processes in aircraft observations of nitric acid and cloud condensation nuclei, J. Geophys. Res., 111, D23S51, doi:10.1029/2006JD007416.

Goode, J. G., R. J. Yokelson, D. E. Ward, R. A. Susott, R. E. Babbitt, M. A Davies, and W. M. Hao (2000), Measurements of excess $\mathrm{O}_{3}, \mathrm{CO}, \mathrm{CO}_{2}$, $\mathrm{CH}_{4}, \mathrm{C}_{2} \mathrm{H}_{6}, \mathrm{C}_{2} \mathrm{H}_{4}, \mathrm{HCN}, \mathrm{NO}, \mathrm{NH}_{3}, \mathrm{HCOOH}, \mathrm{CH}_{3} \mathrm{COOH}, \mathrm{HCHO}$, and $\mathrm{CH}_{3} \mathrm{OH}$ in 1997 Alaskan biomass burning plumes by airborne Fourier transform infrared spectroscopy (AFTIR), J. Geophys. Res., 105, $22,147-22,166$

Hangal, S., and K. Willeke (1990), Overall efficiency of tubular inlets sampling at 0-90 degrees from horizontal aerosol flows, Atmos. Environ., Part A, 24, 2379-2386.

Helmig, D., D. M. Tanner, R. E. Honrath, R. C. Owen, and D. D. Parrish (2008), Non-methane hydrocarbons (NMHC) at Pico Mountain, Azores: 1. Oxidation chemistry in the North Atlantic region, J. Geophys. Res., doi:10.1029/2007JD008930, in press.

Honrath, R. E., R. C. Owen, M. Val Martin, J. S. Reid, K. Lapina, P. Fialho, M. P. Dziobak, J. Kleissl, and D. L. Westphal (2004), Regional and hemispheric impacts of anthropogenic and biomass burning emissions on summertime $\mathrm{CO}$ and $\mathrm{O}_{3}$ in the North Atlantic lower free troposphere, J. Geophys. Res., 109, D24310, doi:10.1029/2004JD005147.

Hudman, R. C., et al. (2007), Surface and lightning sources of nitrogen oxides over the United States: Magnitudes, chemical evolution, and outflow, J. Geophys. Res., D12S05, doi:10.1029/2006JD007912.

Intergovernmental Panel on Climate Change (2007), Climate Change 2007: The Physical Science Basis. Contribution of Working Group I to the Fourth Assessment Report of the Intergovernmental Panel on Climate Change, edited by S. Solomon et al., Cambridge Univ. Press, Cambridge, UK and New York, USA.

Jacob, D. J., J. A. Logan, G. M. Gardner, R. M. Yevich, C. M. Spivakovsky, S. C. Wofsy, S. Sillman, and M. J. Prather (1993), Factors regulating ozone over the United States and its export to the global atmosphere, J. Geophys. Res., 98(D8), 14,817-14,826, doi:10.1029/93JD01224.

Jaeglé, L., L. Steinberger, R. V. Martin, and K. Chance (2005), Global partitioning of $\mathrm{NO}_{x}$ sources using satellite observations: Relative roles of fossil fuel combustion, biomass burning and soil emissions, Faraday Discuss., 130, 407-423, doi:10.1039/b502128f.

Jaffe, D., H. Price, D. Parrish, A. Goldstein, and J. Harris (2003), Increasing background ozone during spring on the west coast of North America, Geophys. Res. Lett., 30(12), 1613, doi:10.1029/2003GL017024.

Kasischke, E. S., and M. R. Turetsky (2006), Recent changes in the fire regime across the North American boreal region: Spatial and temporal patterns of burning across Canada and Alaska, Geophys. Res. Lett., 33 , L09703, doi:10.1029/2006GL025677.

Kleissl, J., R. Honrath, M. Dziobak, D. Tanner, M. Val Martín, R. Owen, and D. Helmig (2007), The occurrence of upslope flows at the Pico mountaintop observatory: A case study of orographic flows on small, volcanic island, J. Geophys. Res., 112, D10S35, doi:10.1029/2006JD007565.

Kley, D., and M. McFarland (1980), Chemiluminescence detector for NO and $\mathrm{NO}_{2}$, Atmos. Technol., 12, 63-69.

Kliner, D., B. Daube, J. Burley, and S. Wofsey (1997), Laboratory investigation of the catalytic reduction technique for measurement of atmospheric $\mathrm{NO}_{y}, J$. Geophys. Res., 102, 10,759-10,776.

Kondo, Y., M. Koike, S. Kawakami, H. B. Singh, H. Nakajima, G. L. Gregory, D. R. Blake, G. W. Sachse, J. T. Merrill, and R. E. Newell (1997), Profiles and partitioning of reactive nitrogen over the Pacific Ocean in winter and early spring, J. Geophys. Res., 102, 28,405-28,424.

Lawrence, M. G., and P. J. Crutzen (1998), The impact of cloud particle gravitational settling on soluble trace gas distributions, Tellus, Ser. B, 50, $263-289$.

Lawrence, M. G., and P. J. Crutzen (1999), Influence of $\mathrm{NO}_{x}$ emissions from ships on tropospheric photochemistry and climate, Nature, 33, $167-170$.

Leue, C., M. Wenig, T. Wagner, O. Klimm, U. Platt, and B. Jahne (2001), Qualitative analysis of $\mathrm{NO}_{x}$ emissions from Global Ozone Monitoring Experiment satellite image sequences, J. Geophys. Res., 106, 5493-5505.

Li, Q., et al. (2002), Transatlantic transport of pollution and its effects on surface ozone in Europe and North America, J. Geophys. Res., 107(D13), 4166, doi:10.1029/2001JD001422.

Li, Q., D. Jacob, J. Munger, R. Yantosca, and D. Parrish (2004), Export of $\mathrm{NO}_{y}$ from the North American boundary layer: Reconciling aircraft observations and global model budgets, J. Geophys. Res., 109, D02313, doi:10.1029/2003JD004086.

Liu, S. C., M. Trainer, F. C. Fehsenfeld, D. D. Parrish, E. J. Williams, D. W. Fahey, G. Hübler, and P. C. Murphy (1987), Ozone production in the rural troposphere and the implications for regional and global ozone distributions, J. Geophys. Res., 92, 4191-4207.

Liu, X., et al. (2006), First directly retrieved global distribution of tropospheric column ozone from GOME: Comparison with the GEOS-Chem model, J. Geophys. Res., 111, D02308, doi:10.1029/2005JD006564.

Logan, J. A. (1983), Nitrogen oxides in the troposphere: Global and regional budgets, J. Geophys. Res., 88, 10,785-10,807.

Martin, R. V., D. D. Parrish, T. B. Ryerson, D. K. Nicks Jr. K Chance, T. P. Kurosu, D. J. Jacob, E. D. Sturges, A. Fried, and B. P. Wert (2004), Validation of GOME satellite measurements of tropospheric $\mathrm{NO}_{2}$ and $\mathrm{HCHO}$ using regional data from aircraft campaigns in the southeastern United States, J. Geophys. Res., 109, D24307, doi:10.1029/ 2004JD004869.

Merrill, J. T., and J. L. Moody (1996), Synoptic meteorology and transport during the North Atlantic Regional Experiment (NARE) intensive: Overview, J. Geophys. Res., 101, 28,903-28,921.

Miyazaki, Y., et al. (2005), Contribution of particulate nitrate to airborne measurements of total reactive nitrogen, J. Geophys. Res., 110(D15), D15304, doi:10.1029/2004JD005502.

Moxim, W. J., H. Levy, and P. S. Kasibhatla (1996), Simulated global tropospheric PAN: Its transport and impact, J. Geophys. Res., 101, $12,621-12,638$

Nesbitt, S. W., R. Whang, and R. Orville (2000), Seasonal and global NO production by lightning estimated from the Optical Transient Detector (OTD), J. Geophys. Res., 52, 1206-1215.

Neuman, J. A., et al. (2006), Reactive nitrogen transport and photochemistry in urban plumes over the North Atlantic Ocean, J. Geophys. Res., 111(D23), D23S54, doi:10.1029/2005JD007010.

Novelli, P. C., L. P. Steele, and P. P. Tans (1992), Mixing ratios of carbon monoxide in the troposphere, J. Geophys. Res., 97, 20,731-20,750.

Novelli, P. C., K. A. Masarie, P. M. Lang, B. D. Hall, R. C. Myers, and J. W. Elkins (2003), Reanalysis of tropospheric CO trends: Effects of the 1997-1998 wildfires, J. Geophys. Res., 108(D15), 4464, doi:10.1029/ 2002JD003031.

Owen, R. C., O. R. Cooper, A. Stohl, and R. E. Honrath (2006), An analysis of the mechanisms of North American pollutant transport to 
the central North Atlantic lower free troposphere, J. Geophys. Res., 111, D23S58, doi:10.1029/2006JD007062.

Parrish, D. D., and F. C. Fehsenfeld (2000), Methods for gas-phase measurements of ozone, ozone precursors and aerosol precursors, Atmos. Environ., 34, 1921-1957.

Parrish, D. D., M. Trainer, E. J. Williams, D. W. Fahey, G. Hübler, C. S. Eubank, S. C. Liu, P. C. Murphy, D. L. Albritton, and F. C. Fehsenfeld (1986), Measurements of the $\mathrm{NO}_{x}-\mathrm{O}_{3}$ photostationary state at Niwo Ridge, Colorado, J. Geophys. Res., 91, 5361-5370.

Parrish, D. D., et al. (1990), Systematic variations in the concentration of $\mathrm{NO}_{x}\left(\mathrm{NO}\right.$ plus $\mathrm{NO}_{2}$ ) at Niwot Ridge, Colorado, J. Geophys. Res., 95, $1817-1836$

Parrish, D. D., et al. (2004), Fraction and composition of $\mathrm{NO}_{y}$ transported in air masses lofted from the North American boundary layer, J. Geophys. Res., 109, D09302, doi:10.1029/2003JD004226.

Peterson, M. C., and R. E. Honrath (1999), $\mathrm{NO}_{x}$ and $\mathrm{NO}_{y}$ over the northwestern North Atlantic: Measurements and measurement accuracy, J. Geophys. Res., 104, 11,695-11,707.

Peterson, M. C., R. E. Honrath, D. D. Parrish, and S. J. Oltmans (1998), Measurements of nitrogen oxides and a simple model of $\mathrm{NO}_{y}$ fate in the remote North Atlantic marine atmosphere, J. Geophys. Res., 103 , $13,489-13,503$

Reeves, C. E., et al. (2007), Alkyl nitrates in outflow from North America over the North Atlantic during Intercontinental Transport of Ozone and Precursors 2004, J. Geophys. Res., 112, D10S37, doi:10.1029/ 2006JD007567.

Richter, A., J. Burrows, H. Nub, C. Granier, and U. Niemeier (2005), Increase in tropospheric nitrogen dioxide over China observed from space, Nature, 437, 129-132, doi:10.1038/nature04092.

Ridley, B. A., and F. E. Grahek (1990), A small, low flow, high sensitivity reaction vessel for NO chemiluminescence detectors, J. Atmos. Technol., 7, 307-311.

Ridley, B., et al. (1998), Measurements of $\mathrm{NO}_{x}$ and PAN and estimates of $\mathrm{O}_{3}$ production over the seasons during Mauna Lao Observatory Photochemistry Experiment 2, J. Geophys. Res., 103, 8323-8339.

Simmonds, P. G., R. G. Derwent, A. L. Manning, and G. Spain (2004), Significant growth in surface ozone at Mace Head, Ireland, 1987-2003, Atmos. Environ., 38, 4769-4778, doi:10.1016/j.atmosenv.2004.04.036.

Singh, H. B., et al. (2007), Reactive nitrogen distribution and partitioning in the North American troposphere and lowermost stratosphere, J. Geophys. Res., 112, D12S04, doi:10.1029/2006JD007664.

Spichtinger, N., M. Wenig, P. James, T. Wagner, U. Platt, and A. Stohl (2001), Satellite detection of a continental-scale plume of nitrogen oxides from boreal forest fires, Geophys. Res. Lett., 28, 4579-4582.

Stohl, A. (1998), Computation, accuracy and applications of trajectories: A review and bibliography, Atmos. Environ., 32, 947-966.

Stohl, A., et al. (2000), The influence of stratospheric intrusions on alpine ozone concentrations, Atmos. Environ., 34, 1323-1354.

Stohl, A., et al. (2003), Rapid intercontinental air pollution transport associated with a meteorological bomb, Atmos. Chem. Phys. Discuss., 3, 969-985.
Stohl, A., C. Forster, A. Frank, P. Seibert, and G. Wotawa (2005), The Lagrangian particle dispersion model FLEXPART version 6.2, Atmos. Chem. Phys. Discuss., 5, 2461-2474.

Thakur, A. N., H. B. Singh, P. Mariani, Y. Chen, Y. Wang, D. J. Jacob, G. Brasseur, J.-F. Müller, and M. Lawrence (1999), Distribution of reactive nitrogen species in the remote free troposphere: Data and model comparisons, Atmos. Environ., 33, 1403-1422.

Thompson, A. M., et al. (2007), Intercontinental Chemical Transport Experiment Ozonesonde Network Study (IONS) 2004: 1. Summertime upper troposphere/lower stratosphere ozone over northeastern North America, J. Geophys. Res., 112, D12S12, doi:10.1029/2006JD007441.

Val Martin, M. (2007), Nitrogen oxides in the North Atlantic Troposphere: Impacts of boreal wildfire and anthropogenic emissions, Ph.D. thesis, Mich. Technol. Univer., Houghton.

Val Martin, M., R. Honrath, R. C. Owen, G. Pfister, P. Fialho, and F. Barata (2006), Significant enhancements of nitrogen oxides, ozone and aerosol black carbon in the North Atlantic lower free troposphere resulting from North American boreal wildfires, J. Geophys. Res., 111, D23S60, doi:10.1029/2006JD007530.

Val Martin, M., R. Honrath, R. C. Owen, and K. Lapina (2008), Large-scale impacts of anthropogenic pollution and boreal wildfires on the nitrogen oxides levels over the central North Atlantic region, J. Geophys. Res., 113, D17308, doi:10.1029/2007JD009689.

Wang, Y., et al. (2003), Springtime photochemistry at northern mid and high latitudes, J. Geophys. Res., 108(D4), 8358, doi:10.1029/ 2002JD002227.

Wenig, M., N. Spichtinger, A. Stohl, G. Held, S. Beirle, T. Wagner, B. Jähne, and U. Platt (2003), Intercontinental transport of nitrogen oxide pollution plumes, Atmos. Chem. Phys. Discuss., 3, 387-393.

Yamamoto, M., M. Tamaki, H. Bandow, and Y. Maeda (2001), $\mathrm{HNO}_{3}$ analyzer by scrubber difference and the $\mathrm{NO}-\mathrm{O}_{3}$ chemiluminescence method, Atmos. Environ., 35, 5339-5346.

Yang, J., et al. (2002), Impacts of snowpack emissions on deduced levels of $\mathrm{OH}$ and peroxy radicals at Summit, Greenland, Atmos. Environ., 36 $2523-2534$

Zellweger, C., J. Forrer, P. Hofer, S. Nyeki, B. Schwarzenbach, E. Weingartner, M. Ammann, and U. Baltensperger (2003), Partitioning of reactive nitrogen $\left(\mathrm{NO}_{y}\right)$ and dependence on meteorological conditions in the lower free troposphere, Atmos. Chem. Phys. Discuss., 3, 779-796.

R. E. Honrath and R. C. Owen, Department of Civil and Environmental Engineering, Michigan Technological University, 1400 Townsend Drive, Houghton, MI 49931, USA. (reh@mtu.edu; rcowen@mtu.edu)

Q. B. Li, Jet Propulsion Laboratory, California Institute of Technology, 4800 Oak Grove Drive, Pasadena, CA 91109, USA.

M. Val Martin, School of Engineering and Applied Sciences, Harvard University, Pierce 193, 29 Oxford Street, Cambridge, MA 02138, USA (mvalmart@seas.harvard.edu) 